\title{
The Impact of Ethical standards including Ethical Environment, Professional Commitment, Ethical Values and Ethical Ideology on Performance of Auditors
}

\author{
Parviz Shayesteh Shojaei \\ PhD. Student of Accounting, Central Tehran Branch, Islamic Azad University, \\ Tehran, Iran(parviz.shayesteh@yahoo.com) \\ Zahra Poorzamani * \\ Professor of Accounting group, Central Tehran Branch, Islamic Azad University, \\ Tehran, Iran(Corresponding Author), zahra.poorzamani@yahoo.com \\ Ahmad Yaghobnezhad \\ Associate Professor of Accounting group, Central Tehran Branch, Islamic Azad \\ University, Tehran, Iran(ahm.yaghobnezhad@iauctb.ac.ir)
}

\begin{abstract}
:
The present study was an attempt to investigate the effect of ethical standards including ethical environment (instrumental environment, favorite environment, independent environment, normative environment, efficiency-based environment and regulation-oriented environment), professional commitment, ethical values and ethical ideology (idealism and relativism) on performance of auditors. The population of this study consists of auditors of auditing firms affiliated with Iranian association of Certified Public Accountants and certified independent auditors. To calculate the number of samples and to take samples, coceran fornulation and the avilable sample methods have been respectively used. This study was conducted in 2020.300 auditors participated in the present study and completed the questionnaires distributed among them. The partial least squares (PLS) method was used for modelling and hypothesis testing purposes. The results show that all the subsets of ethical environment (instrumental environment, favorite environment, independent environment, normative environment, efficiency-based environment and regulation-oriented environment) have a positive and significant correlation with auditor performance. As for the subsets of ethical ideology, idealism and relativism were found to have a significantly positive and a significantly negative correlation with the performance of auditors, respectively. The
\end{abstract}


Semiannually journal of Value \& Behavioral Accounting dof $10.52547 / \mathrm{aapc} .5 .10 .281$

results also show that the main variables of the study (ethical environment, professional commitment, ethical values and ethical ideology) have a positive and significant effect on the occupational performance of auditors. Applying the results of this research can help to develop theoretical foundations in the field of the ethical behavior in auditors as well as to increase their level of awareness and ethical development. It also increases the understanding of auditors' behavior in the face of ethical conflicts.

Keywords: Ethical Behavior، Auditor Performance، Professional Commitment، Ethical Values، Ethical Ideology.

\section{Copyrights}

This license only allowing others to download your works and share them with others as long as they credit you, but they can't change them in any way or use them commercial. 


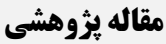

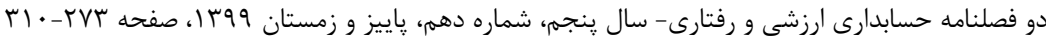

\section{تاثير معيار هاى رفتار اخلاقى (شامل محيط اخلاقى، تعهد حرفهاى، ارزشهاى اخلاقى و ايدئولوزى اخلاقى) بر عملكرد حسابر سان}

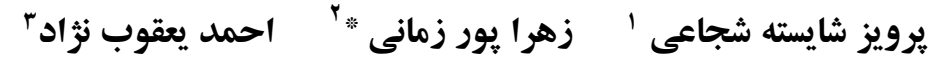

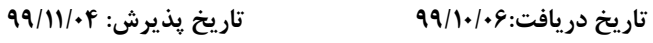

\begin{abstract}
جكيده
اين مطالعه به بررسى تاثير معيارهاى رفتار اخلاقى شامل محيط اخلاقى(محيط ابزارى، محيط

دلخواه، محيط مستقل، محيط ضوابط، محيط كارايى محور و محيط قانون و مقررات)، تعهد حرفهاى، ارزشهاى اخلاقى و ايدئولوزى اخلاقى(ايدهآل گرايى و نسبى آرايى) بر عملكرد

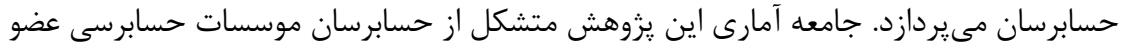

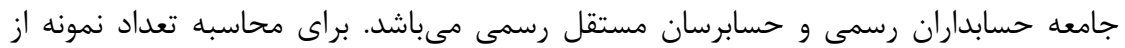

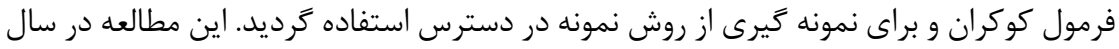

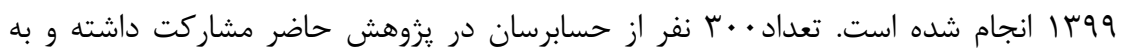

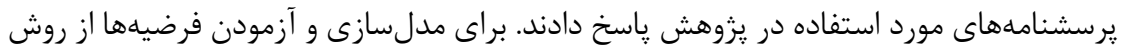
حداقل مربعات جزئى (PLS) استفاده شده است. نتايج نشان مىدهد، تمام متغيرهاى زير مجموعه محيط اخلاقى (شامل محيط ابزارى، محيط دلخواه، محيط مستقل، محيط ضوابط،

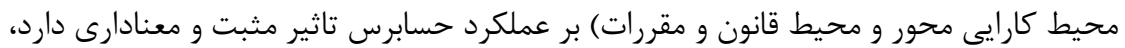

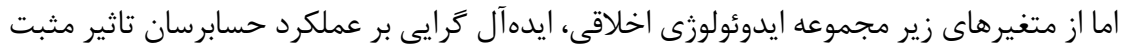

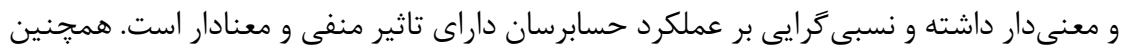

$$
\begin{aligned}
& \text { 'دانشجو دكترى حسابدارى، واحد تهران مركزى، دانشعاه آزاد اسلامى، تهران، ايران } \\
& \text { (parviz.shayesteh@yahoo.com) } \\
& \text { 'استاد گروه حسابدارى، واحد تهران مركزى، دانشعاه آزاد اسلامى، تهران، ايران (نويسنده مسئول) } \\
& \text { zahra.poorzamani@yahoo.com } \\
& \text { ‘ّانشيار گروه حسابدارى، واحد تهران مركزى، دانشعاه آزاد اسلامى، تهران، ايران } \\
& \text { Ahm.yaghobnezhad@iauctb.ac.ir }
\end{aligned}
$$




$$
\begin{aligned}
& \text { نتايج نشان مىدهد، متغيرهاى اصلى يزوهش شامل محيط اخلاقى، تعهد حرفهاى، ارزشهاى }
\end{aligned}
$$

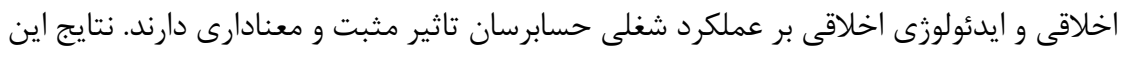

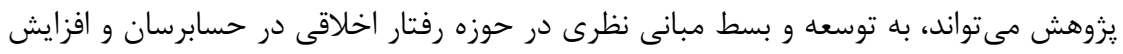

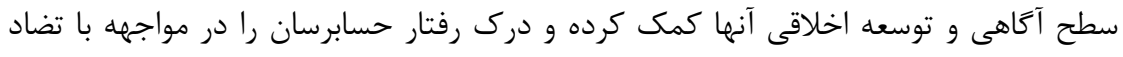

$$
\begin{aligned}
& \text { اخلاقى افزايش دهد. } \\
& \text { وازگًان كليدى: رفتار اخلاقى، عملكرد حسابرس، تعهد حرفهاى، ارزشهاى اخلاقى، }
\end{aligned}
$$

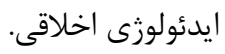




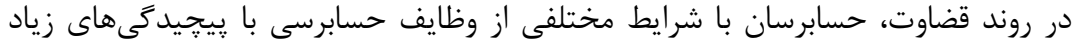

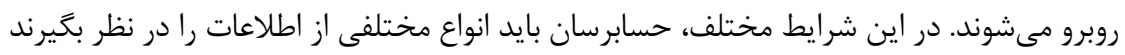

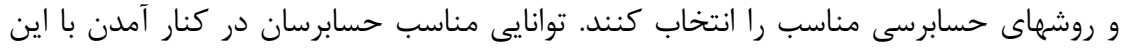

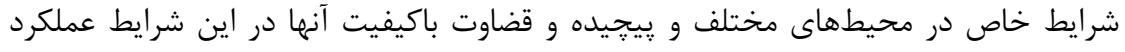

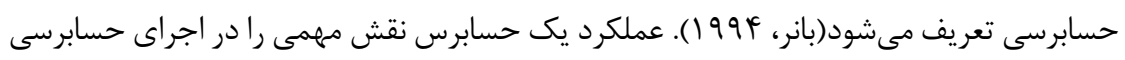
ايفا مى كند تا بتواند سهامداران، سرمايه كذاران، اعتباردهند سازد كه صورتهاى مالى ارايهشده ياسخكو و معتبر هستند.

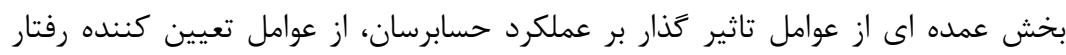

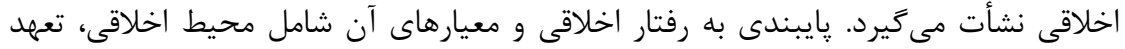

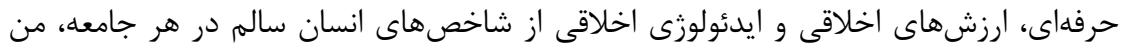
جمله حسابرسان مىباشد.

در ايران بازار حسابرسى خصوصى يا حسابرسى هاى برونسيارى شده دولتى مانند حسابرسى

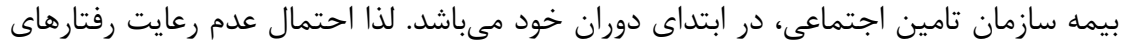

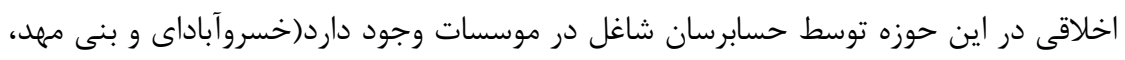

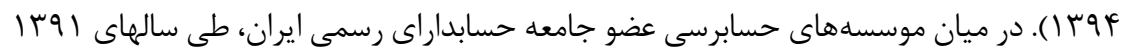

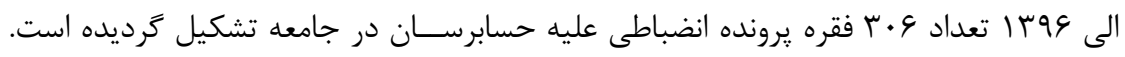

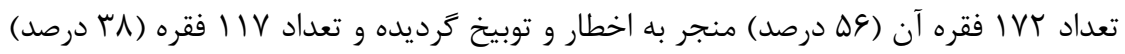

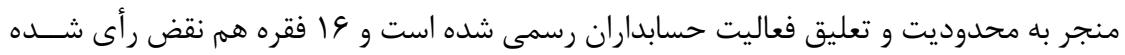

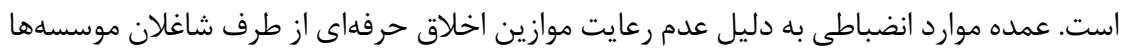

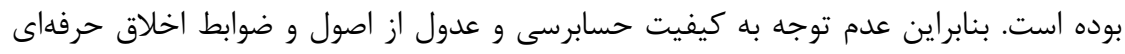

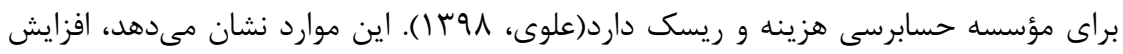
دانش حسابرسان در حوزه قوانين رفتار اخلاقى و رعايت موازين اخلاقى در حرفه حسابرسى درى داني

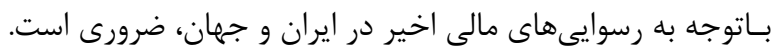

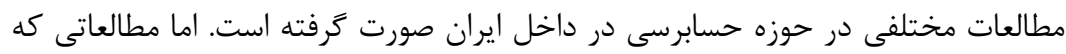

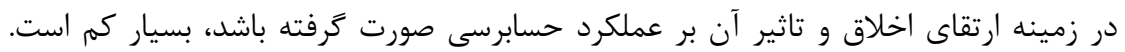
نشريههاى داخلى حسابدارى و حسابرسى هم نقش موثرى در اين زمينه ايفا نكردهاند. لذا بايد

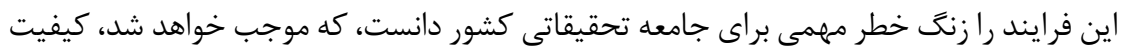

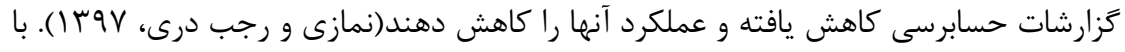

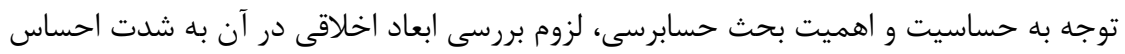


مىشود. از طرف ديكر اهميت ويزهاى كه عملكرد حسابرسان بهعنوان عاملى مهم و اثركذار بر

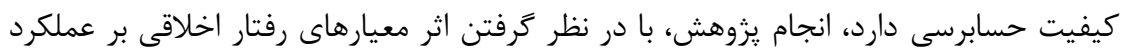
حسابرسان لازم به نظر مىرسد.

از اين رو يرسش اصلى اين يزوهش آن است كه معيارهاى رفتار اخلاقى ( محيط اخلاقى،

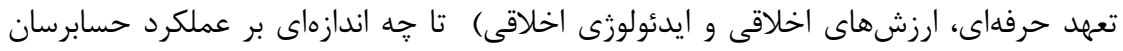

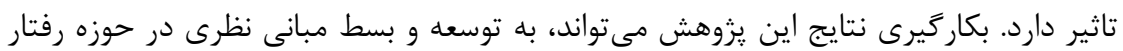

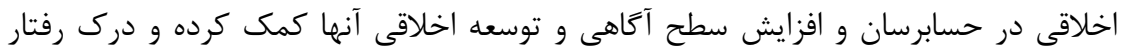

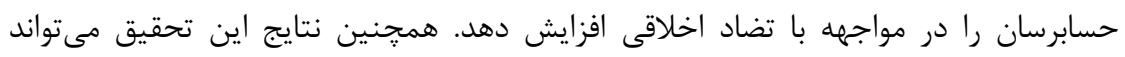

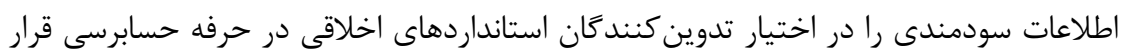

\section{r- مبانى نظرى و بيشينه يخوهش}

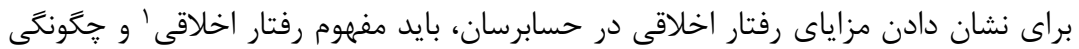

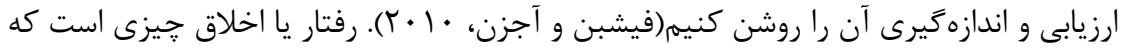

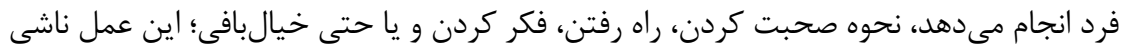

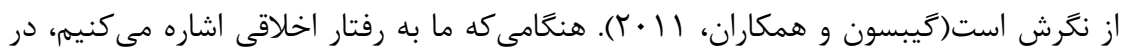

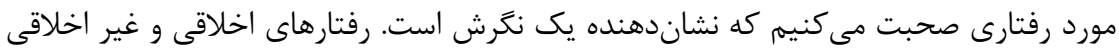

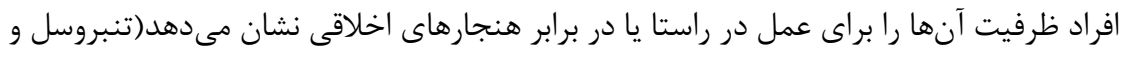

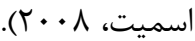
مطالعات نشان داده است، حسابرسان اغلب با مشكل اخلاقى در انجام وظايف خود مواجه

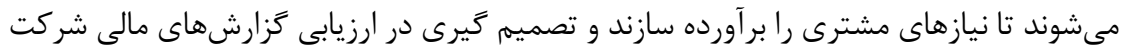

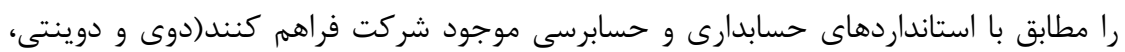

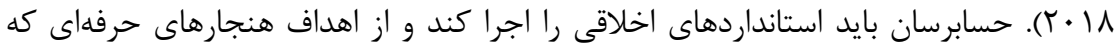

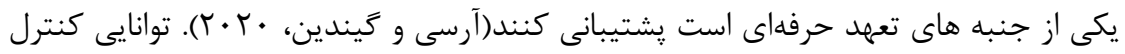

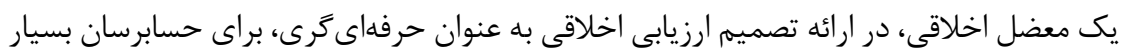

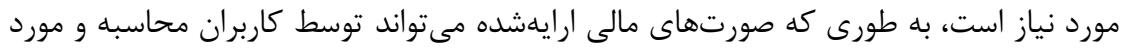

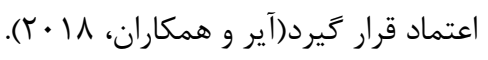

${ }^{1}$ Ethical behavior 
براى اينكه بتوانيم تاثير رفتار اخلاقى را بر عملكرد حسابرسان مورد بررسى قرار دهيم، ابتدا

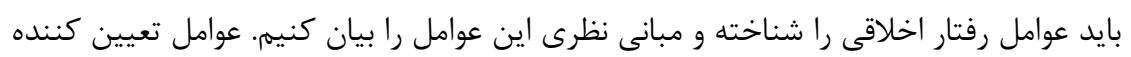

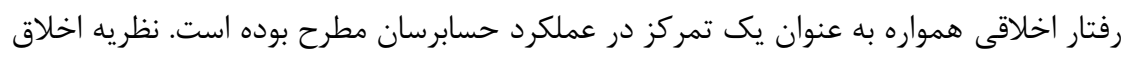

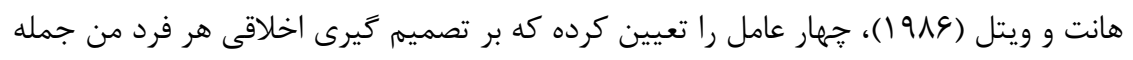

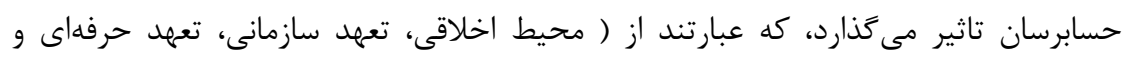

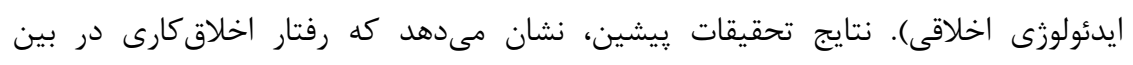

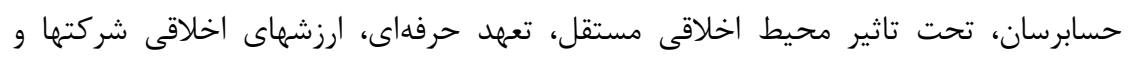

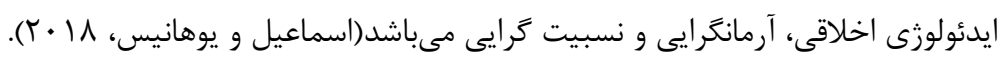

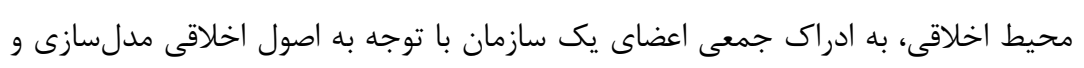

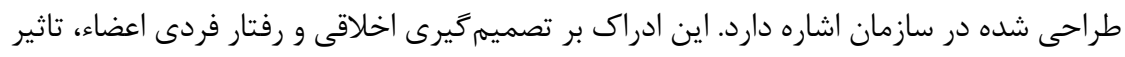

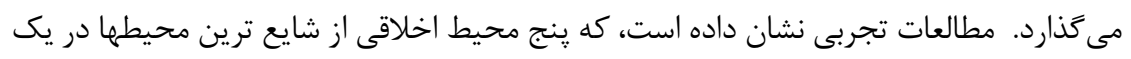

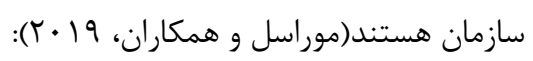

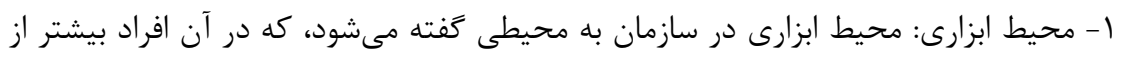

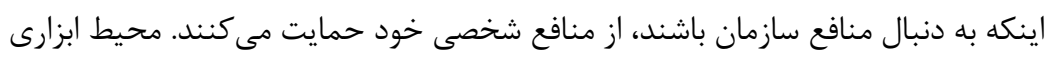

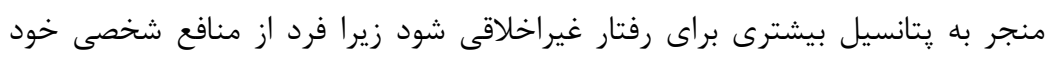

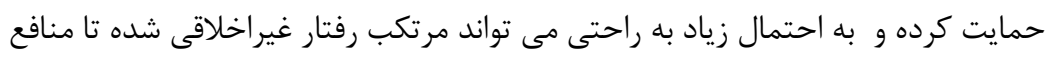
شخصى خود را انجام دهد(اسماعيل، ها • (؟).

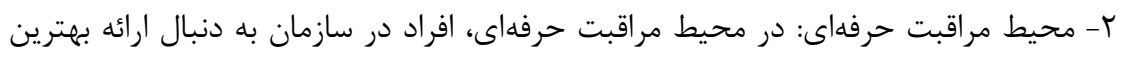

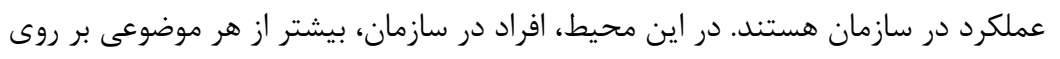

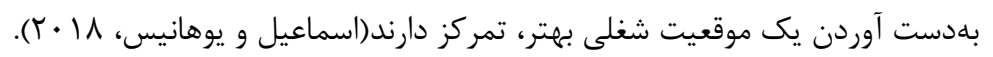

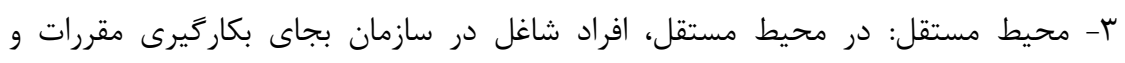

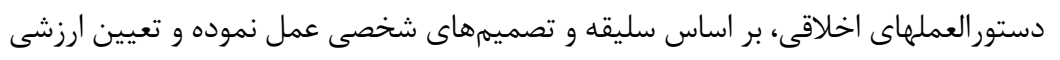

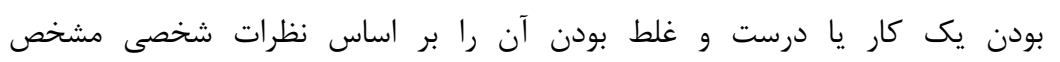

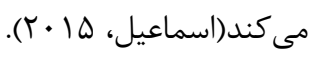

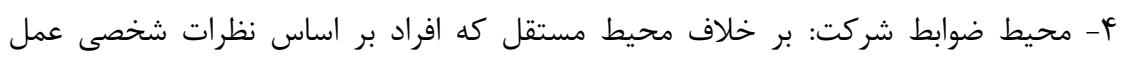

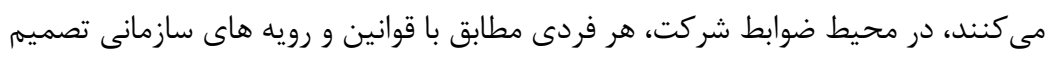

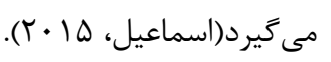
ه- محيط كارايى محور: در محيط كارايى محور، افراد شاغل در سازمان، كنترل هزينهاهـا را در

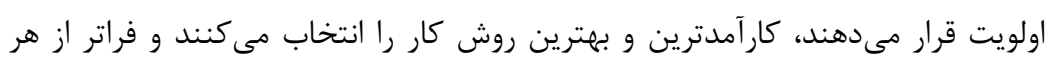

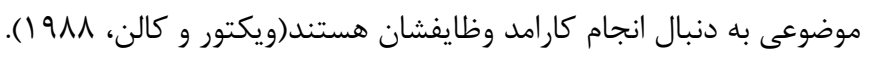


צ- محيط قانون و مقررات: در محيط قانون و مقررات، افراد بدون توجه به نظرات شخصى و بدون

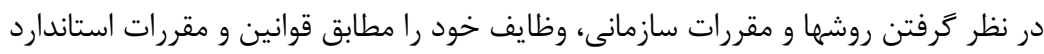

$$
\text { حرفه انجام مى دهند(اسماعيل، صا • (T). }
$$

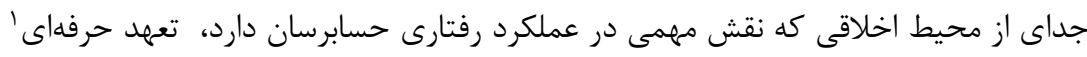

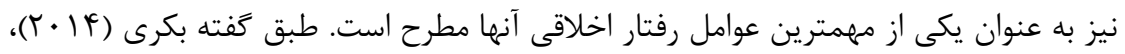

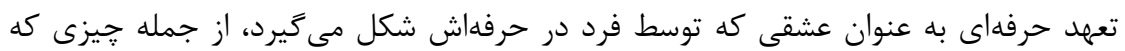

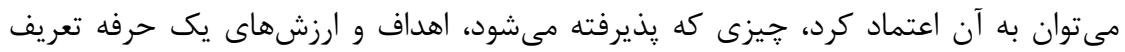
مىشود.

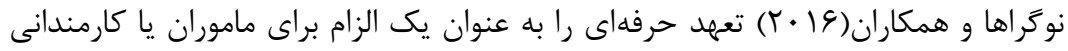

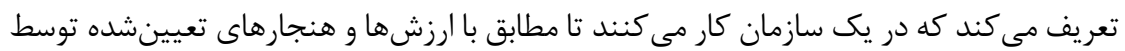
استانداردهاى حرفهاى رفتار كنند.

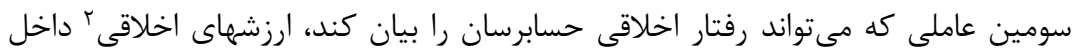
سازمان است. ارزشهاى اخلاقى شركت، تركيبى از ارزشهاى اخلاقى مديران فردى در سازمان و واندان

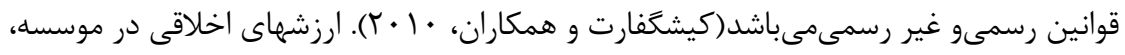

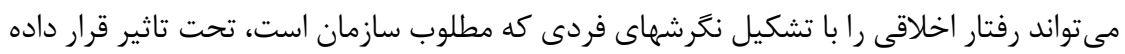

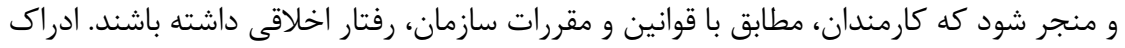

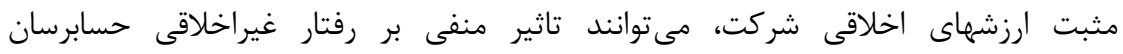

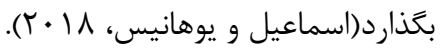

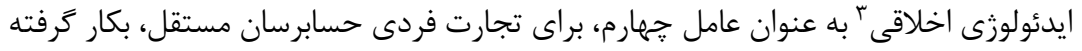

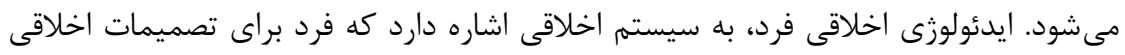

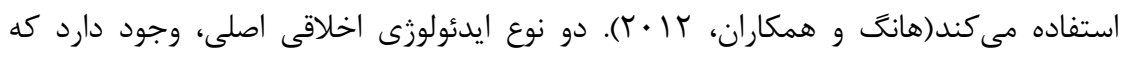

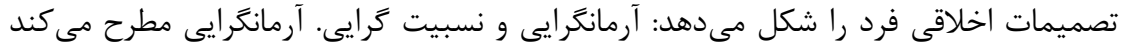

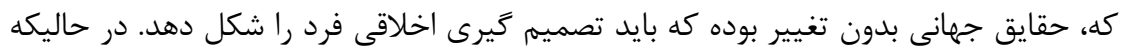

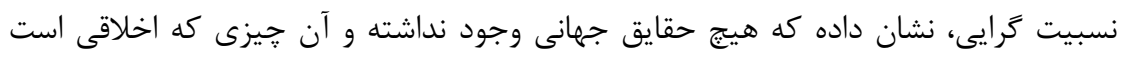

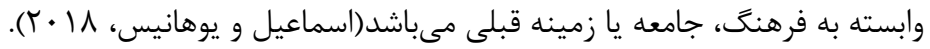

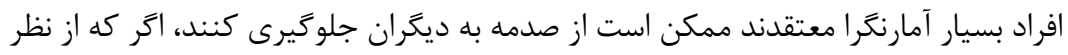

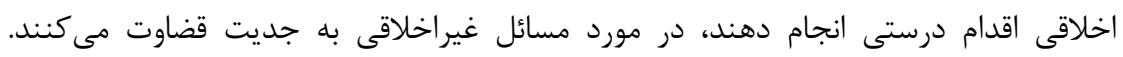

1 professional committment

2 Moral Values

3 Moral ideology 
درحاليكه، افراد بسيار نسبى كرا كه به شدت قوانين و مقررات مطلق را رد مي كنند اما عوامل

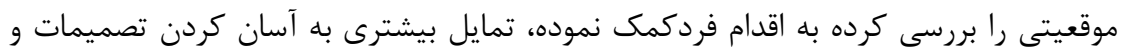

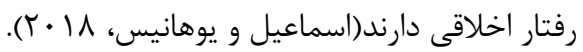
با بررسى و جستجو در مقالات منتشر شده در مجلات داخلى و خارجى، كمتر مقالدالى داري، تاثير

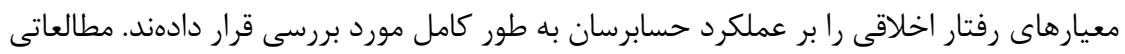

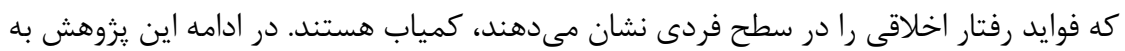
بررسى مقالات نزديك در حوزه تحقيق اشاره مى كردد.

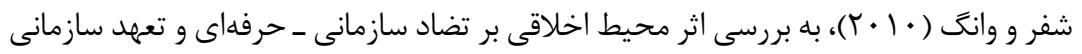

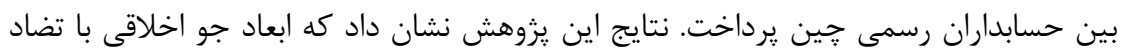

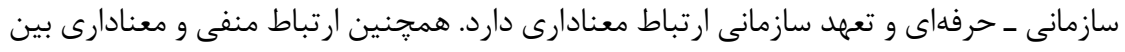

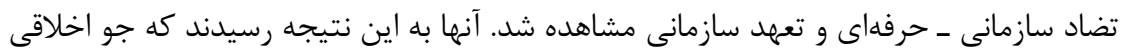

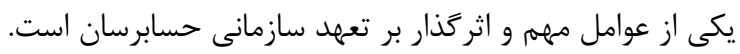

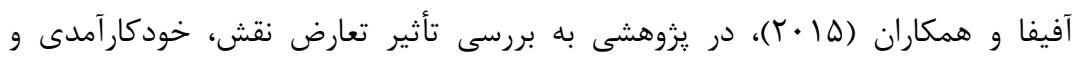

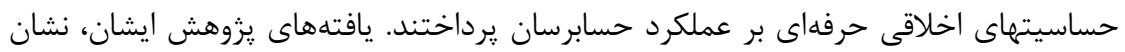

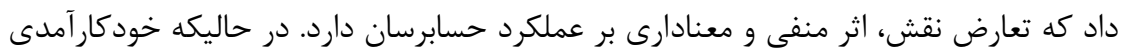

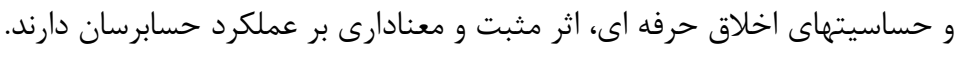

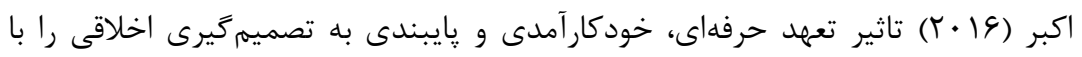

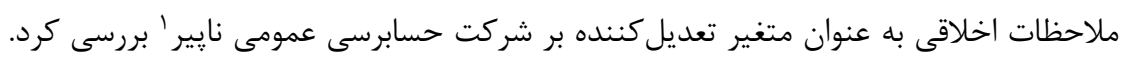

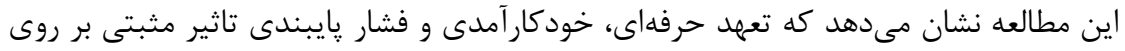
تصميم

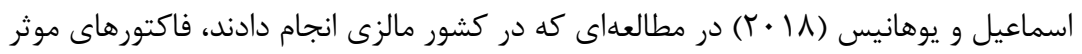
بر رفتار كار اخلاقى حسابرسان در بخش دولتى مالزى را مدلسازى كردند. نتايج منجر به ارائه

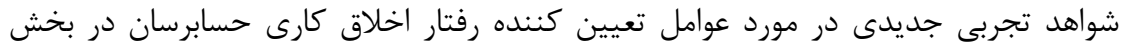
دولتى اقتصاد در حال توسعه مالزى كرديد دريد.

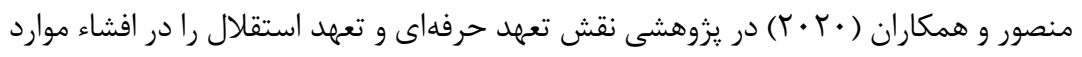

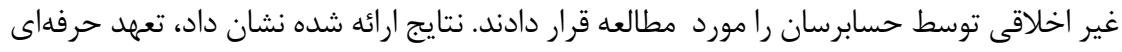

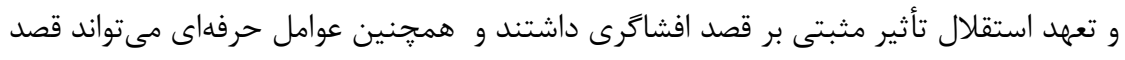

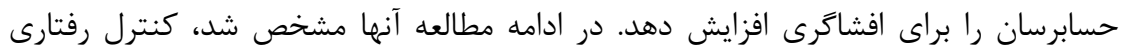


دركشده يك تاثير مثبت و معنى دار بر افشاكرى داشته، در حالى كه مدركى كه نشان دهد،

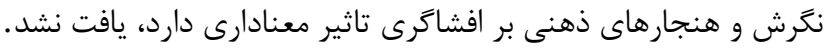

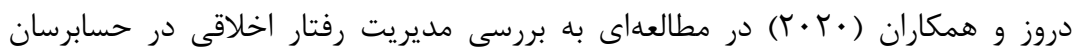
يرداختند. نتايج اين تحقيق نشان داد، مىتوان از استانداردهاى آزمون اخلاقى و معيارهاى

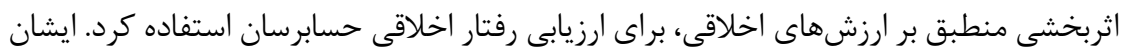

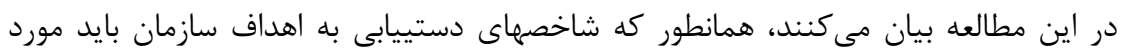

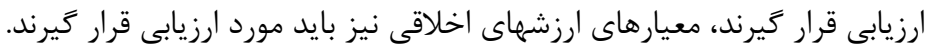

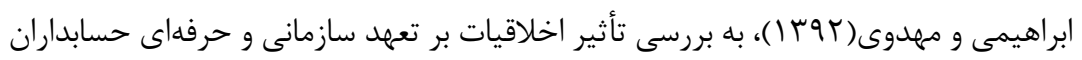

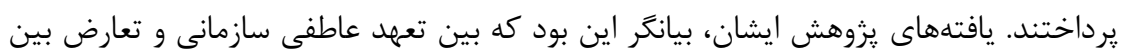
حرفه و سازمان، رابطه منفى و معنادارى وجود دارد دئ.

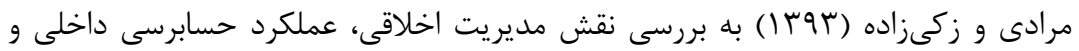

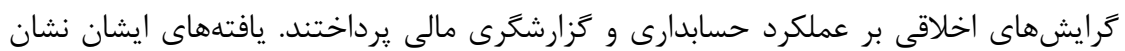

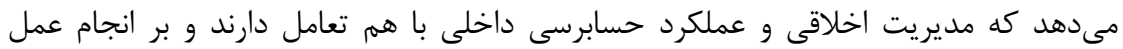

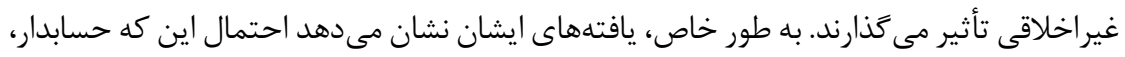

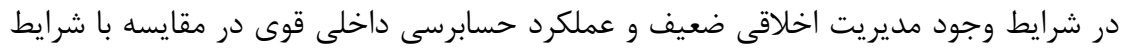
ديكر، يك عمل غيراخلاقى انجام دهد، كمتر است. در مجموع، نتايج حاكى از آن است كه

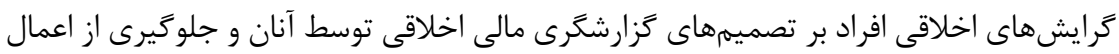

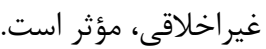

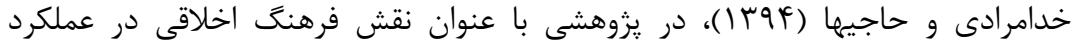

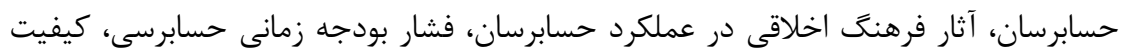

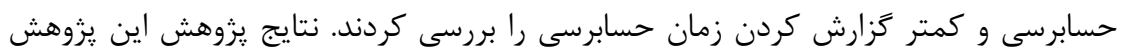

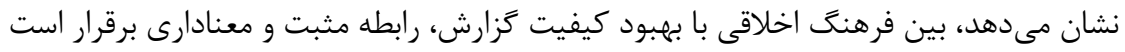

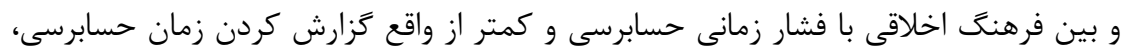

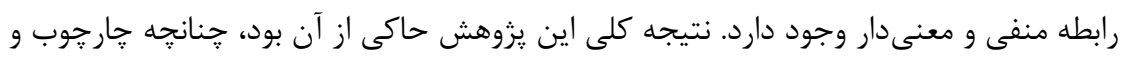

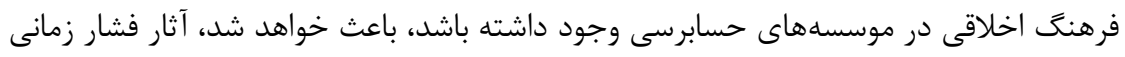

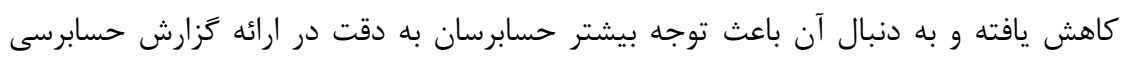

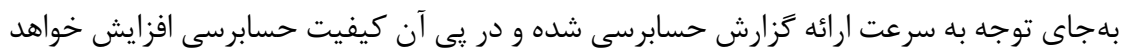

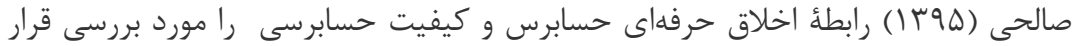

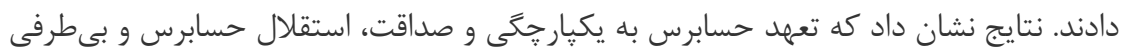


حرفهاى او، تعهد حسابرس به رفتار حرفهاى در حرفه حسابرسى، تعهد حسابرس بر عملكرد حرفهاى حسابرس اثر مثبت و معنادارى دارد دارد

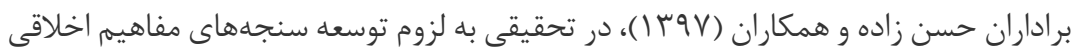

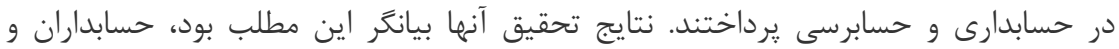

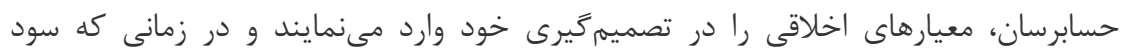

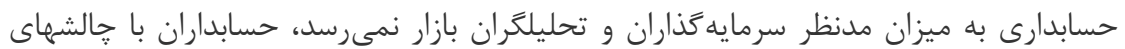
اخلاقى عمده اي روبه رو مىشوند.

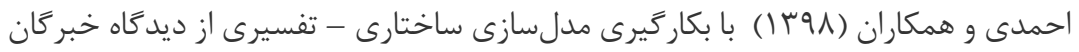

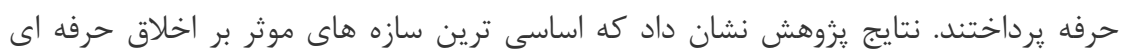

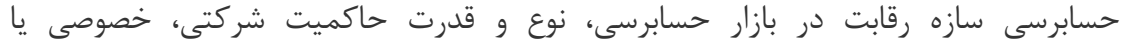

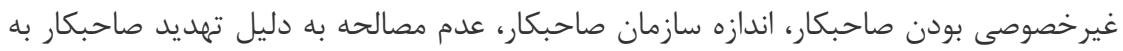
بركنارى حسابرس، مشكلات مالى حسابرس و نوسانات اقتصاد است. باغوميان و رجب درى (99 () در مطالعهاى رابطه بين ايدئولوزى اخلاقى و استرس

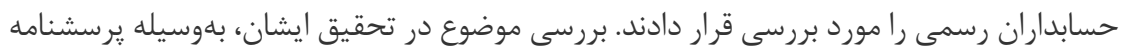

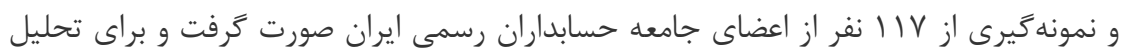

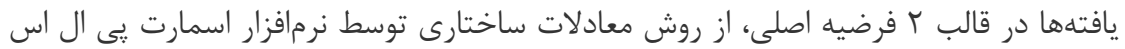

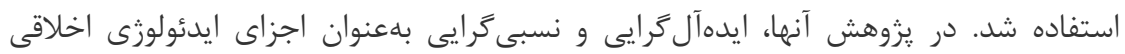

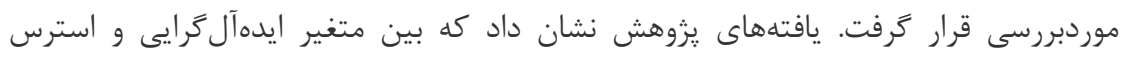

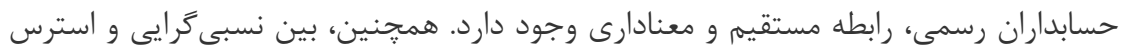

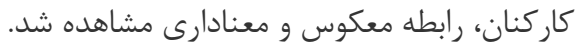

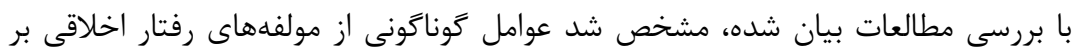
عملكرد حسابرسان و نهايتا بر كيفيت گزارشهاى حسابرسى تاثير كذار است. هر يك از تحان تحقيقات

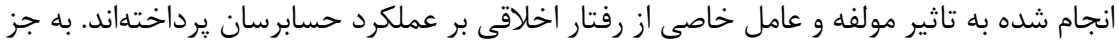

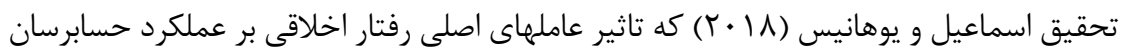
را مورد بررسى قرار دادهاند، يروهش ديخرى در اين حوزه ياقت نكرديد. اين موضوع در تحقيقات

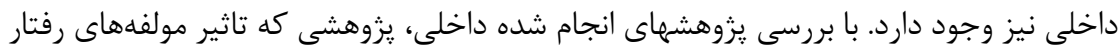

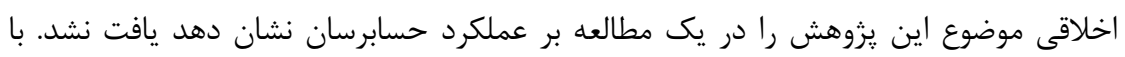
توجه به خلاء هاى موجود در تحقيقات انجام شده، در اين يزوهش به بر برسى تاثير مولفههاى رفتار اخلاقى (محيط اخلاقى، تعهد حرفهاى، ارزشهاى اخلاقى و ايدئولوزى اخلاقى) بر عملكرد

$$
\text { حسابرسان مىيردازيم. }
$$


بر اساس يزوهشهاى انجام شده و با تاكيد بر يزوهش انجام شده توسط اسماعيل و يوهانيس

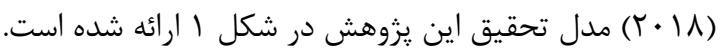

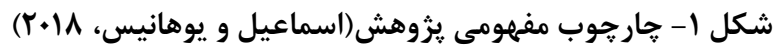

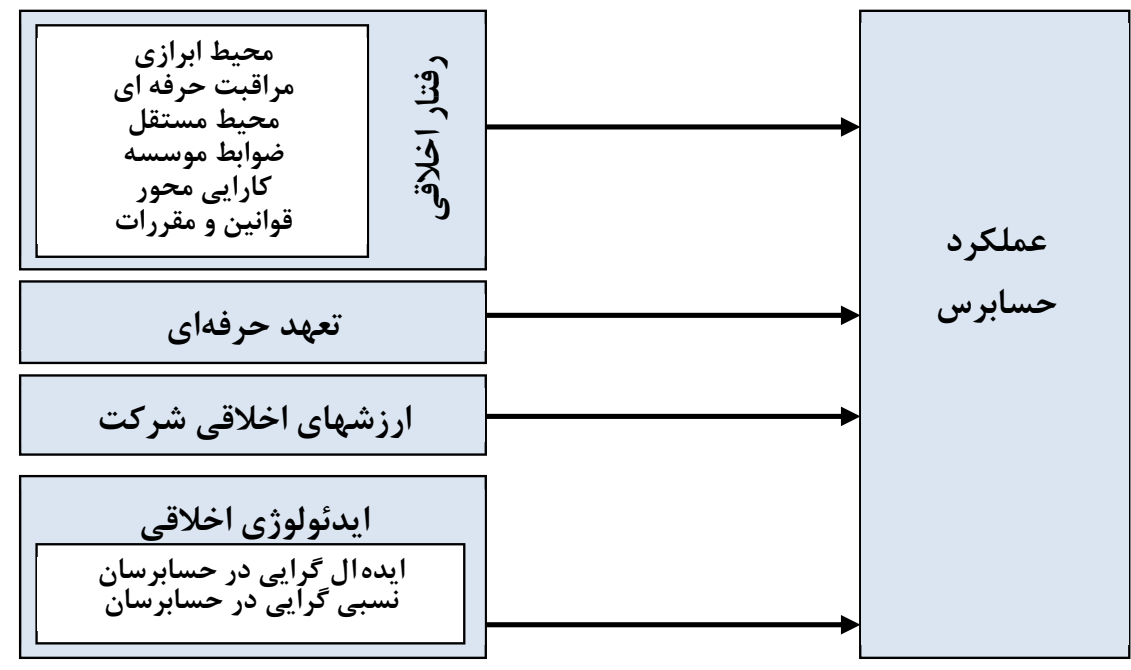

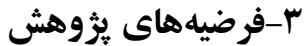

بر اساس مفاهيهم و مبانى نظرى يزوهش، موضوع و متغيرهاى يزوهش، فرضيههاى اين مطالعه به صورت زير تعريف ميكردد.

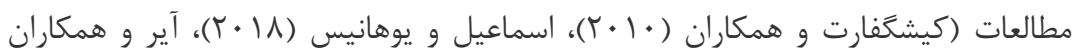

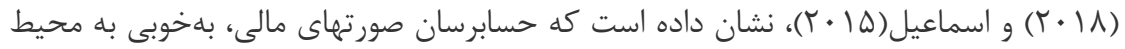

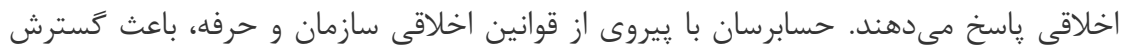

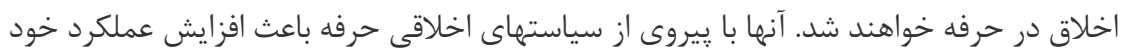

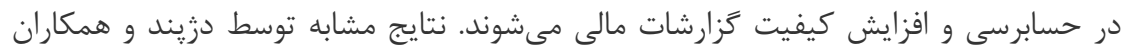

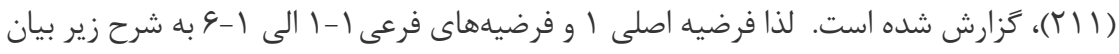

فرضيه اصلى ا- محيط اخلاقى، تاثير مثبت و معنادارى بر عملكرد حسابرسان دارد.

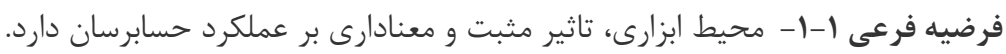

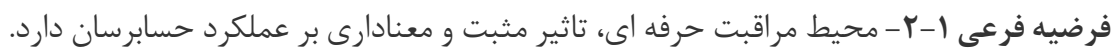

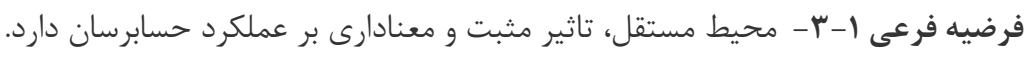


فرضيه فرعى أ-F- محيط ضوابط موسسه، تاثير مثبت و معنادارى بر عملكرد حسابرسان دارد. فرضيه فرعى ا-ه- - محيط كارايى محور، تاثير مثبت و معنادارى بر عملكرد حسابرسان دارد. فرضيه فرعى ا-4- محيط قوانين و مقر رات، تاثير مثبت و معنادارى بر عملكرد حسابرسان دارد. در بخش مبانى نظرى، علاوه بر محيط اخلاقى، تعهد حرفهاى نيز به عنوان يكى از عاملهاى

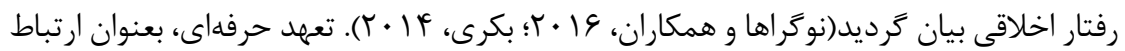
قوى بين فرد و حرفه وى بيان مىشود. انتظار مىرود حسابرسانى كه تعهد بالايى به حردان حرفه خود

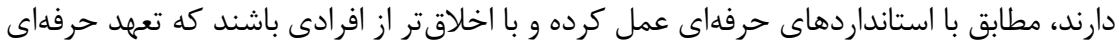

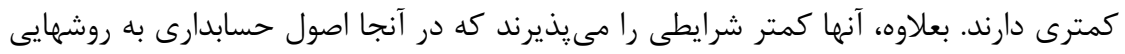

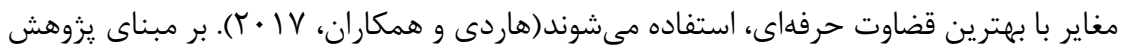
انجام شده، فرضيه اصلى T به شرح زير بيان مى تردد. فرضيه اصلى Y - تعهد حرفه اي در حسابرسان، تاثير مثبت و معنادارى برعملكردحسابرسان دارد. ارزشهاى اخلاقى شركت به عنوان سومين عامل رفتار اخلاقى، منعكس كننده هويت يا

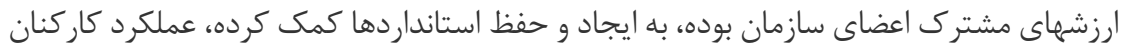

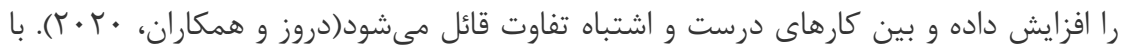

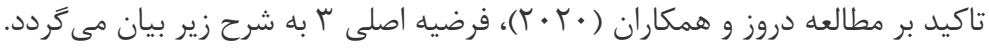
فرضيه اصلى بـ- ارزشهاى اخلاقى شركت، تاثير مثبت و معنادارى بر عملكرد حسابرسان دارد. مطابق مطالعات انجام شده در حوزه رفتار اخلاقى كه در مبانى نظرى بيان گَرديد، ايدئولوزى

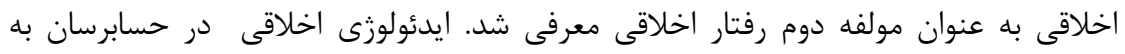

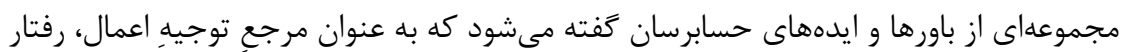

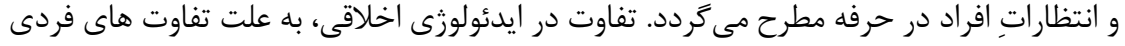

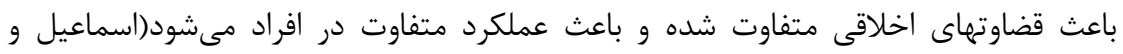

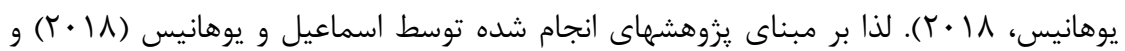

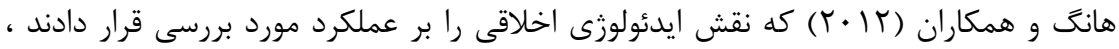

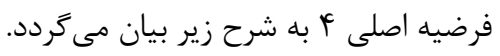

فرضيه اصلى F- ايدئولوزى اخلاقى درحسابرسان، تاثير مثبت و معنادارى بر عملكرد حسابرسان

فورسايت (•191) ، ايدئولوزى اخلاقى را حد فاصل ايده آل كرائى و نسبيتكرايى تعريف

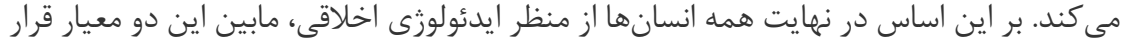

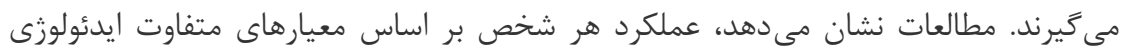




$$
\begin{aligned}
& \text { اخلاقى منحصر به فرد است (يور و همكاران، ها • (Y). بر اساس مطالعات بيان شده، فرضيههاى }
\end{aligned}
$$

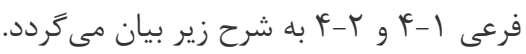

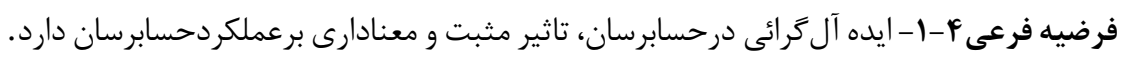

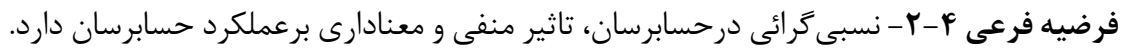

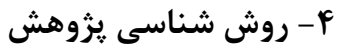

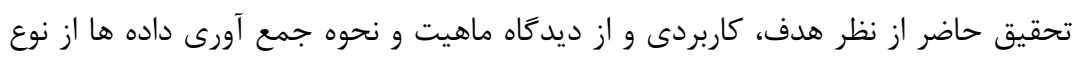

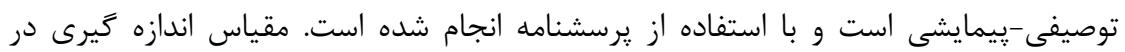

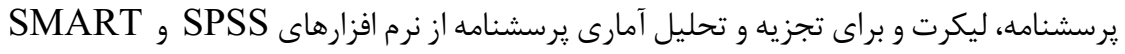

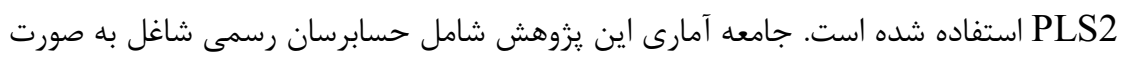

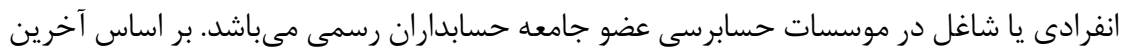

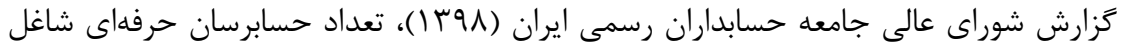

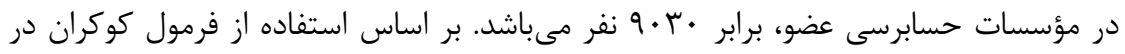

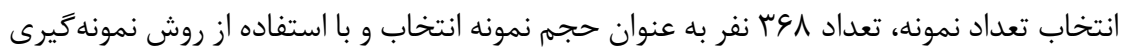

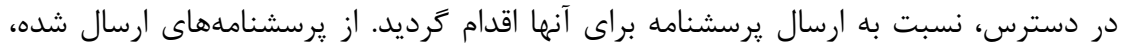

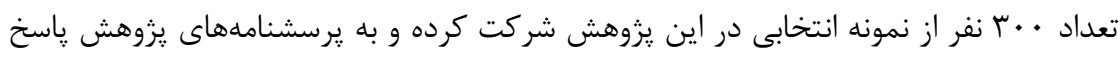

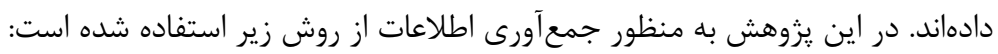

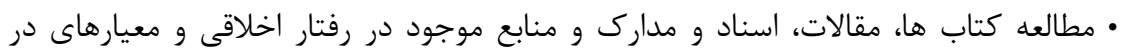
حسابرسان

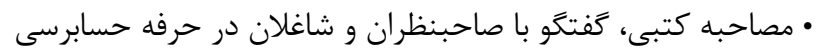

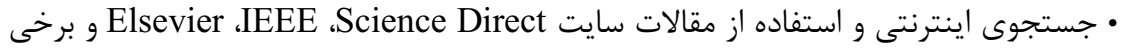

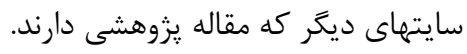

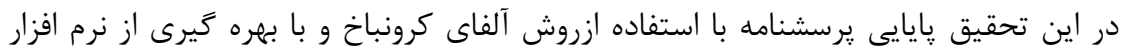

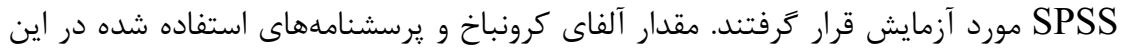

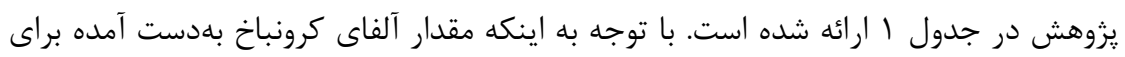

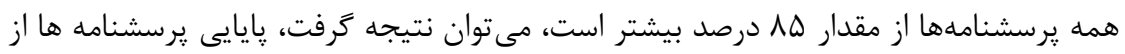

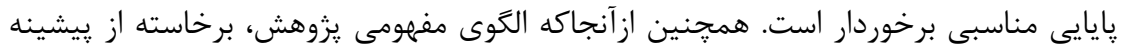

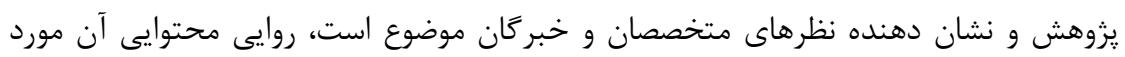
تأييد است. 
شايسته شجاعى و همكاران، تاثير معيارهاى رفتار اخلاقى بر عملكرد حسابرسان

\begin{tabular}{|c|c|c|}
\hline \multicolumn{3}{|c|}{ جدول ا- يرسشنامههاى استفاده شده در يزوهش } \\
\hline كرونباخ & 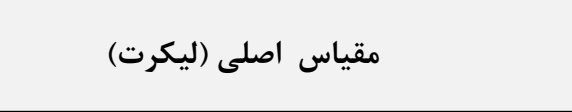 & 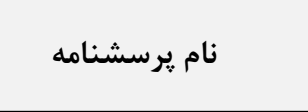 \\
\hline.$/ 999$ & روشه امتيازى ( (= كاملاً مخالفو ه= كاملا موافق) & 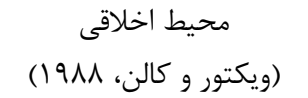 \\
\hline.$/ 994$ & روشه امتيازى( (= كاملا مخالف و ه= كاملا موافق) & 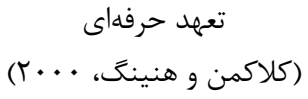 \\
\hline$\cdot / \wedge \wedge \Delta$ & روش V امتيازى( = = كاملا مخالف و V= كاملا موافق) & 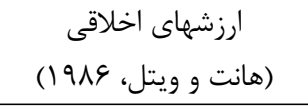 \\
\hline$\cdot / 9 \cdot 1$ & روش 9 امتيازى( (= كاملا مخالف و 9= كاملا موافق) & 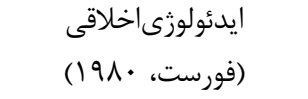 \\
\hline$\cdot / 941$ & روشه امتيازى ( = كاملا مخالف و ه= كاملا موافق) & 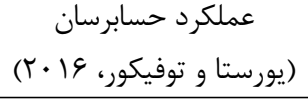 \\
\hline
\end{tabular}

\section{ه- يافته هاى يزوهش}

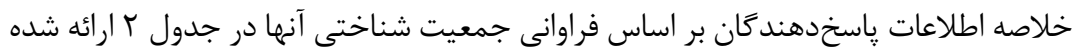

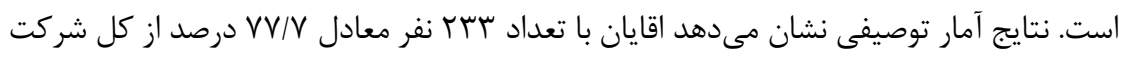

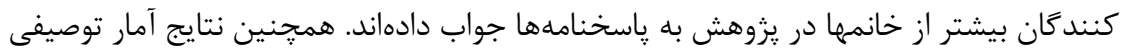

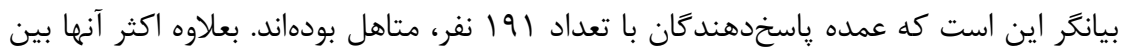

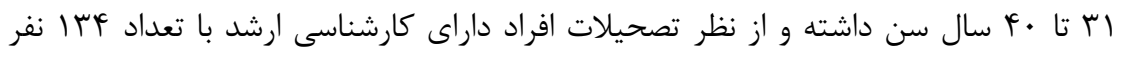

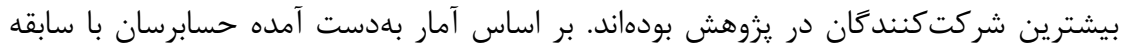

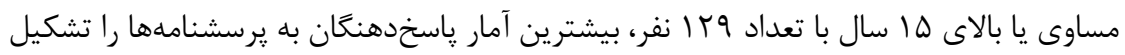

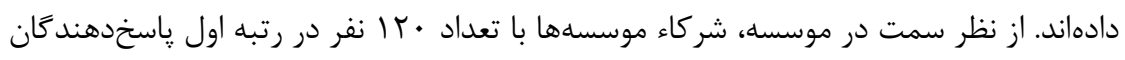

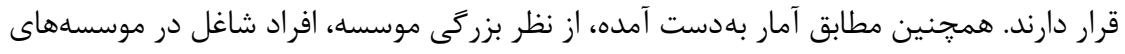

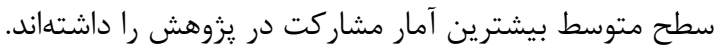


دو فصلنامه حسابدارى ارزشى و رفتارى، سال ينجم، شماره دهم، پإييز و زمستان و9جا

دول Y- جدول فراوانى جمعيت شناختى ياسخكَويان به يرسشنامه

\begin{tabular}{|c|c|c|c|}
\hline درصد & فراوانى & \multicolumn{2}{|c|}{ شرح } \\
\hline$T T / T$ & $9 V$ & زن & \multirow{2}{*}{ جنسيت } \\
\hline$V V / V$ & מדr & مرد & \\
\hline qr/V & 191 & متاهل & \multirow{2}{*}{ وضعيت تاهل } \\
\hline re/r & 1.9 & مجرد & \\
\hline $9 / \mu$ & $r \Lambda$ & كمتر از • ب سال & \multirow{4}{*}{ سن } \\
\hline $4 q$ & IFV & بين آ⿱ تا • بال & \\
\hline$r \Lambda$ & $\Lambda f$ & بين أ تا • D سال & \\
\hline$I T / V$ & il & بيشتر از اله سال & \\
\hline 每 & $1 \cdots$ & دكترى & \multirow{3}{*}{ ميزان تحصيلات } \\
\hline$F F / V$ & IMF & فوق ليسانس & \\
\hline tr & 99 & ليسانس & \\
\hline $14 / \pi$ & Fr & ه سال و كمتر & \multirow{4}{*}{ سابقه حرفهاى } \\
\hline$r \cdot$ & 9. & و تا • ا سال & \\
\hline$T Y / V$ & 91 & | ا تا ها سال & \\
\hline Fr & 1199 & بيشتر از هاسال & \\
\hline$I F / V$ & FF & حسابرس & \multirow{6}{*}{ موقعيت در موسسه } \\
\hline s/V & $r \cdot$ & حسابرس ارشد & \\
\hline $10 / \mu$ & 14 & سريرست & \\
\hline $9 / \pi$ & 19 & سريرست ارشد & \\
\hline$r$. & IT. & شريك & \\
\hline IV & $\Delta 1$ & مدير & \\
\hline 1 & $r$ & تك مالكى & \multirow{4}{*}{ اندازه موسسه حسابرسى } \\
\hline$V / r$ & rt & كوجك & \\
\hline$\uparrow \wedge / V$ & 149 & متوسط & \\
\hline Fr & 119 & بزرگ & \\
\hline $1+$. & $r .$. & & كا \\
\hline
\end{tabular}

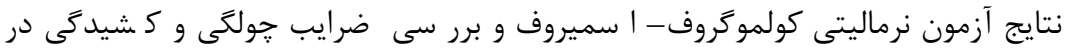

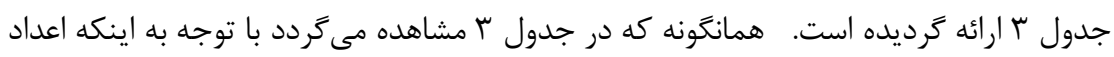

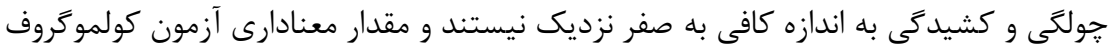

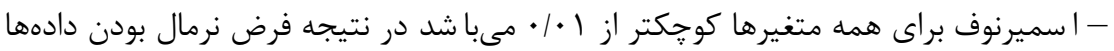

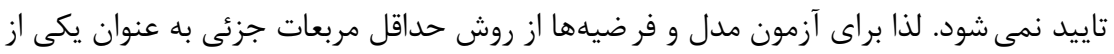

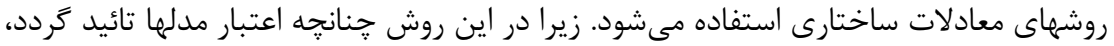

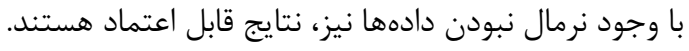


شايسته شجاعى و همكاران، تاثير معيارهاى رفتار اخلاقى بر عملكرد حسابرسان

\section{جدول - نتايج آزمون نرماليتى (آزمون كولموكروف - اسميرنوف)}

\begin{tabular}{|c|c|c|c|c|}
\hline كشيدكى & جولَى & مقدار معنادارى & آماره آزمون & ن ام متغير \\
\hline$-1 / T V T$ &.$- .1 .1 \mathrm{~V}$ & $\cdot / \cdots$ & $\cdot 11 \cdot 0$ & مراقبت حرفه اى \\
\hline$-1 / T F \theta$ & $-\cdot / \cdot V V$ & $\% \cdots$ & .1109 & قوانين و مقررات \\
\hline$-\cdot 1 \Delta \Delta V$ & $-\cdot / r \Delta \Lambda$ & $.1 \cdots$ &.$/ 1 \vee \wedge$ & ضوابط موسسه \\
\hline$-1 / 1 V \Delta$ & -.1 .90 & $.1 \cdots$ & $\cdot 11 \cdot 1$ & محيط ابزارى \\
\hline$-1 / 191$ & -.1 .90 & $\cdot 1 \cdot$ & $\cdot 110$ & كارايى محور \\
\hline$-1 / Y F T$ & $-\cdot 1 \cdot \cdot 1$ & $\cdot 1 \cdot$ &.$/ I V T$ & محيط مستقل \\
\hline.$- / F T Y$ & $\% r$ & $.1 \cdots$ & .1 .49 & محيط اخلاقى \\
\hline$r / r 99$ & $1 / 0 / F$ & $\cdot 1 \cdot$ & $.11 \vee 9$ & ايده آل كرايى \\
\hline-.1949 & $\cdot \pi \Delta \varphi$ & $\cdot 1 \cdot$ & .1110 & نسبى ترايى \\
\hline$-1 / \cdot k r$ & .1119 & $\cdot 1 \cdot$ & . 11 He & ايدئولوزى اخلاقى \\
\hline$-\cdot|\Delta \Lambda|$ & $\cdot \pi r$ & $\cdot 1 \cdot$ & $.11 \vee 9$ & تعهد حرفه اى \\
\hline-.1911 & $-\cdot 11 \cdot 9$ & $\cdot \cdots$ & $\cdot 1109$ & ارزش هاى اخلاقى \\
\hline$-\cdot 19 \wedge \Delta$ & $-.1 .4 \wedge$ & $\cdot \cdots$ & $\cdot / \cdot v 9$ & ملكرد شغلى حسابر سار \\
\hline
\end{tabular}

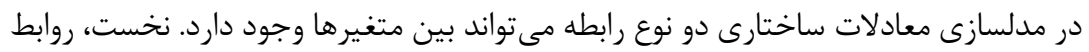

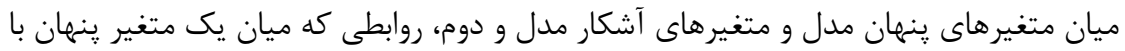

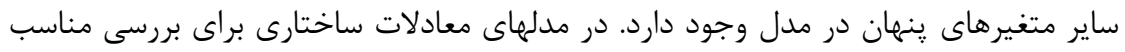

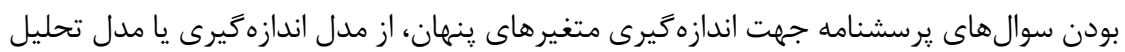

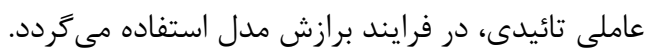

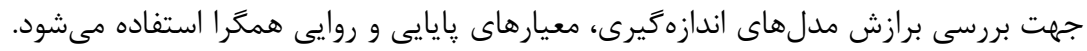

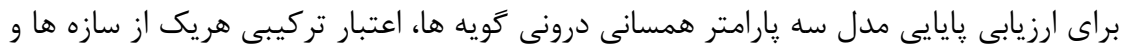

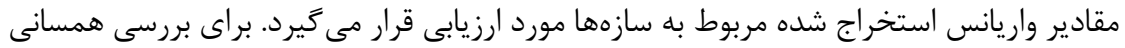

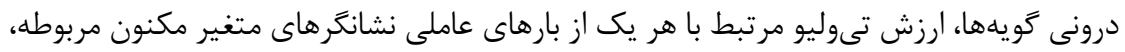

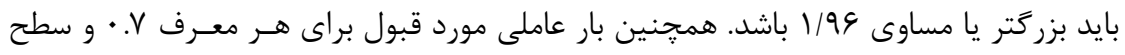

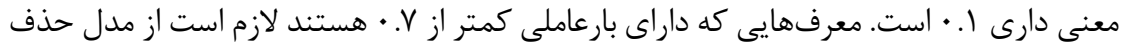

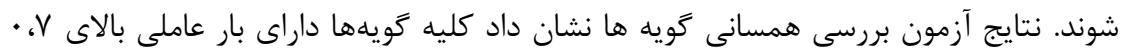

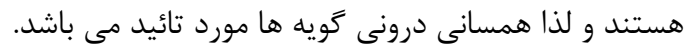


بررسى اعتبار تركيبى هريك از سازه ها

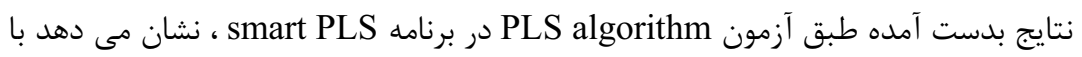

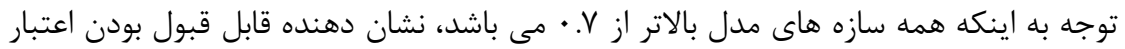

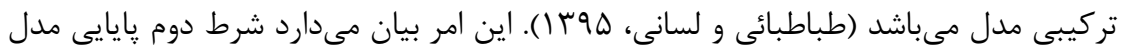

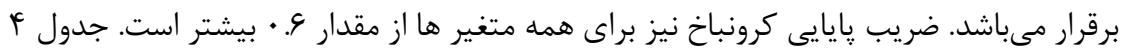

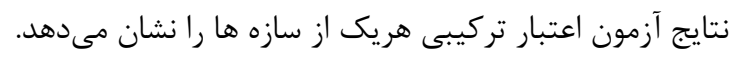

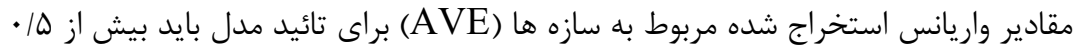

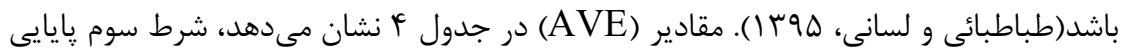
مدل محقق شده است و مقدار واريانس استخراج شده براى هريك از سازه ها بيش از مقدار قابل دابل

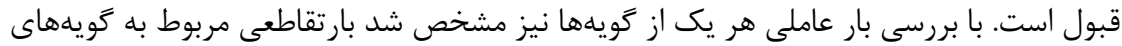

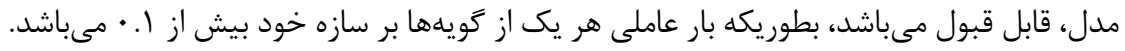

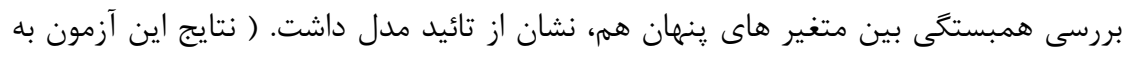

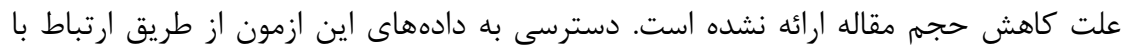

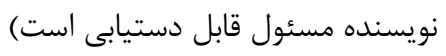

جدول F - بررسى اعتبار تركيبى هريك از سازه ها

\begin{tabular}{|c|c|c|c|}
\hline مقادير واريانس استخراج شده مازه ها (AVE) & هريك از سازه هار اعتبـ & آلفاى كرونباخ & سازه ها \\
\hline . IATF & .1909 &.$/ 949$ & مراقبت حرفه اى \\
\hline س ram. & $.191 \mathrm{r}$ &.$/ 9 \vee 9$ & قوانين و مقررات \\
\hline .1981 &.$/ 99$. & $\cdot / 9 \wedge \Delta$ & ضوابط موسسه \\
\hline$\cdot|\Lambda| f$ & .1991 & .1991 & محيط ابزارى \\
\hline.$/ 9 \mathrm{FT}$ &.$/ 91$. &.$/ 9 \mathrm{~V}$. & كارايى محور \\
\hline .1948 &.$/ 914$ &.$/ 9 \mathrm{VV}$ & محيط مستقل \\
\hline$\cdot / \Delta T \cdot$ & .1910 & $\cdot / 9 \cdot r$ & ايده آل گرايى \\
\hline . $|\Delta T|$ & .1914 & .1911 & نسبى گرايى \\
\hline.$/ 9 T F$ & .1990 &.$/ 994$ & تعهد حرفه اى \\
\hline$\cdot \mid 9 \wedge \Delta$ & .1919 & $\cdot / \wedge \wedge \Delta$ & ارزش هاى اخلاقى \\
\hline$\cdot \mid \Delta S V$ &.$/ 94 \lambda$ &.$|94|$ & عملكرد شغلى حسابرسان \\
\hline
\end{tabular}


شايسته شجاعى و همكاران، تاثير معيارهاى رفتار اخلاقى بر عملكرد حسابرسان




دو فصلنامه حسابدارى ارزشى و رفتارى، سال پِنجم، شماره دهم، پاييز و زمستان 99سا

$r q$.

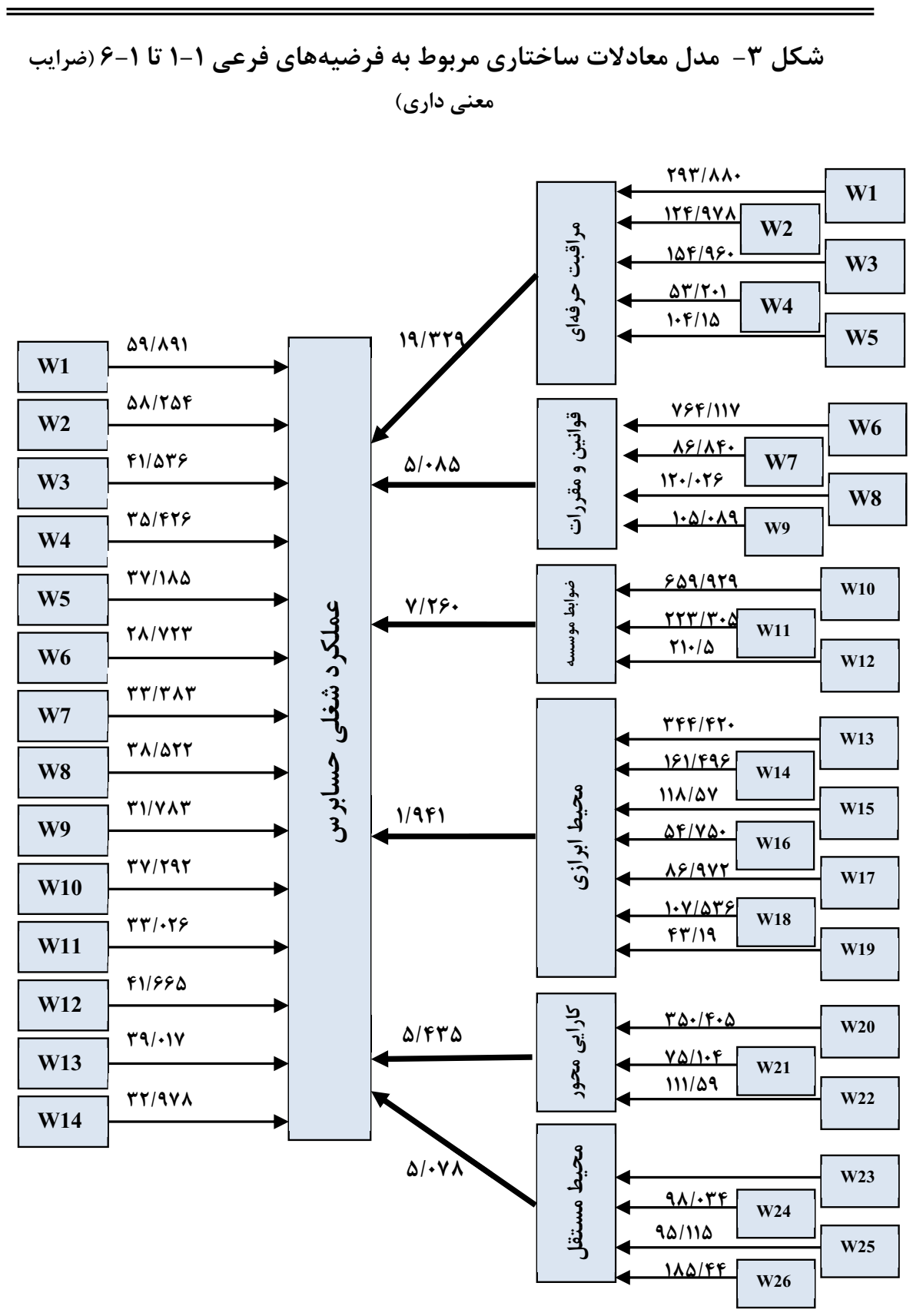




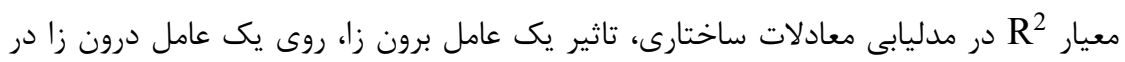

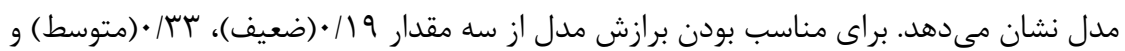

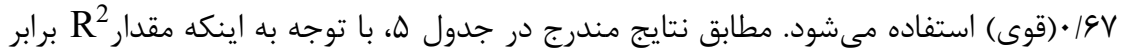

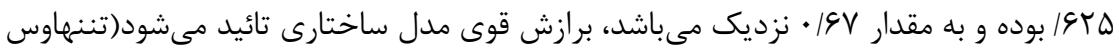

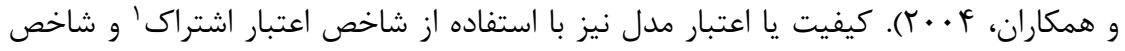

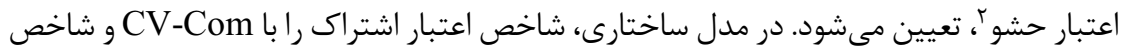

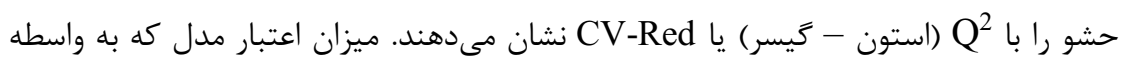

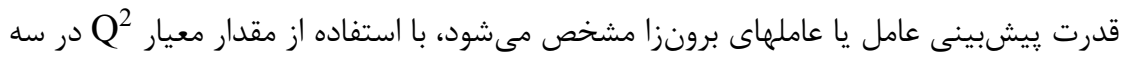

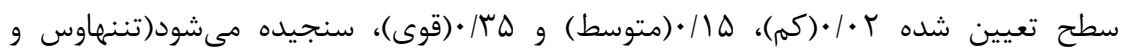

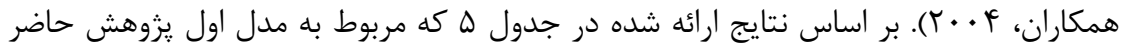

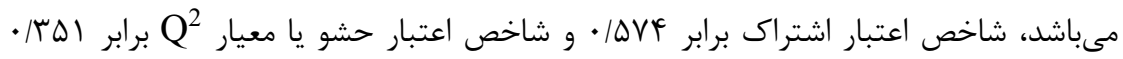
است. لذا بر اساس مقايسه مقادير بلددستآمده با مقادير ارزيابى اين شاخصمها، كيفيت يا اعتبار اعتبار

$$
\text { مدل در سطح قوى مورد تائيد قرار مى كيرد. }
$$

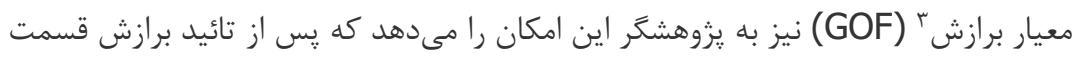

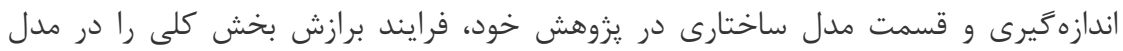

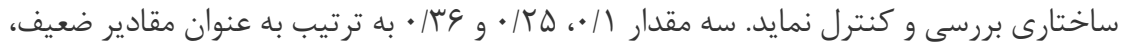

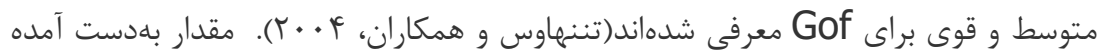

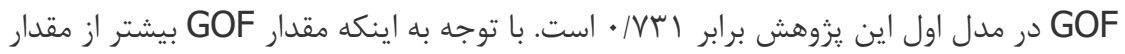

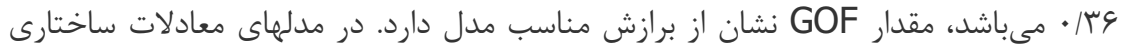

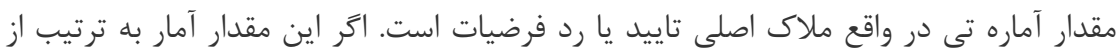

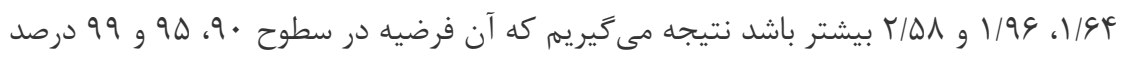

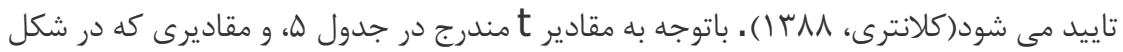

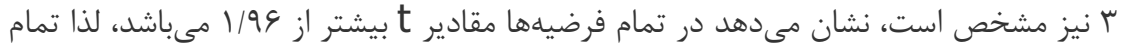

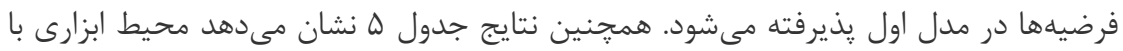

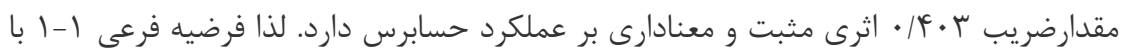

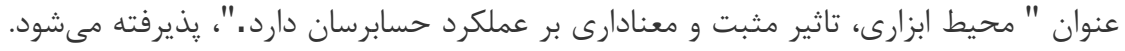

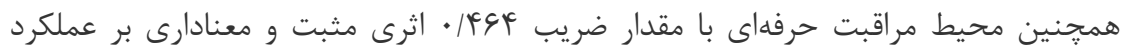

1 Cross validated Communality (CV-Com)

2 Cross validated redundancy (CV-Red)

3 Goodness of fit (GoF) 
حسابرس دارد. لذا فرضيه فرعى ا-Y نيز با عنوان " محيط مراقبت حرفه اى، تاثير مثبت و

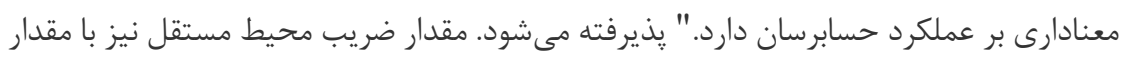

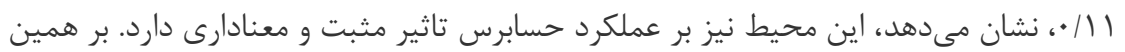

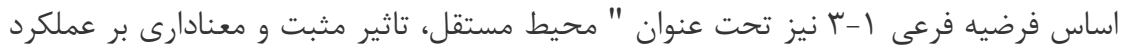

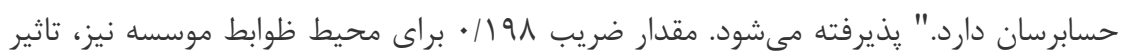

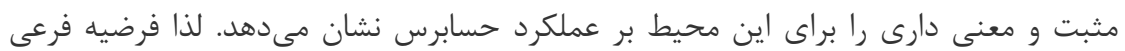

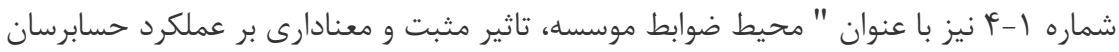

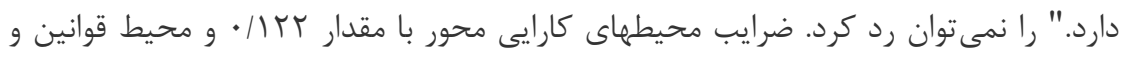

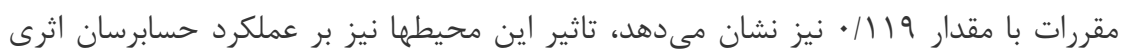

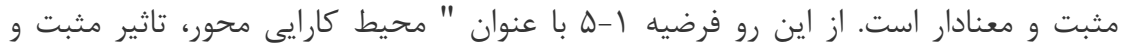

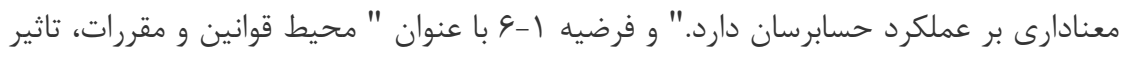

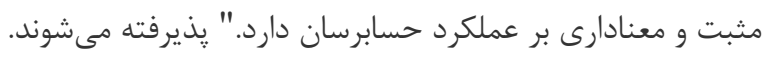

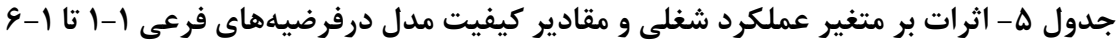

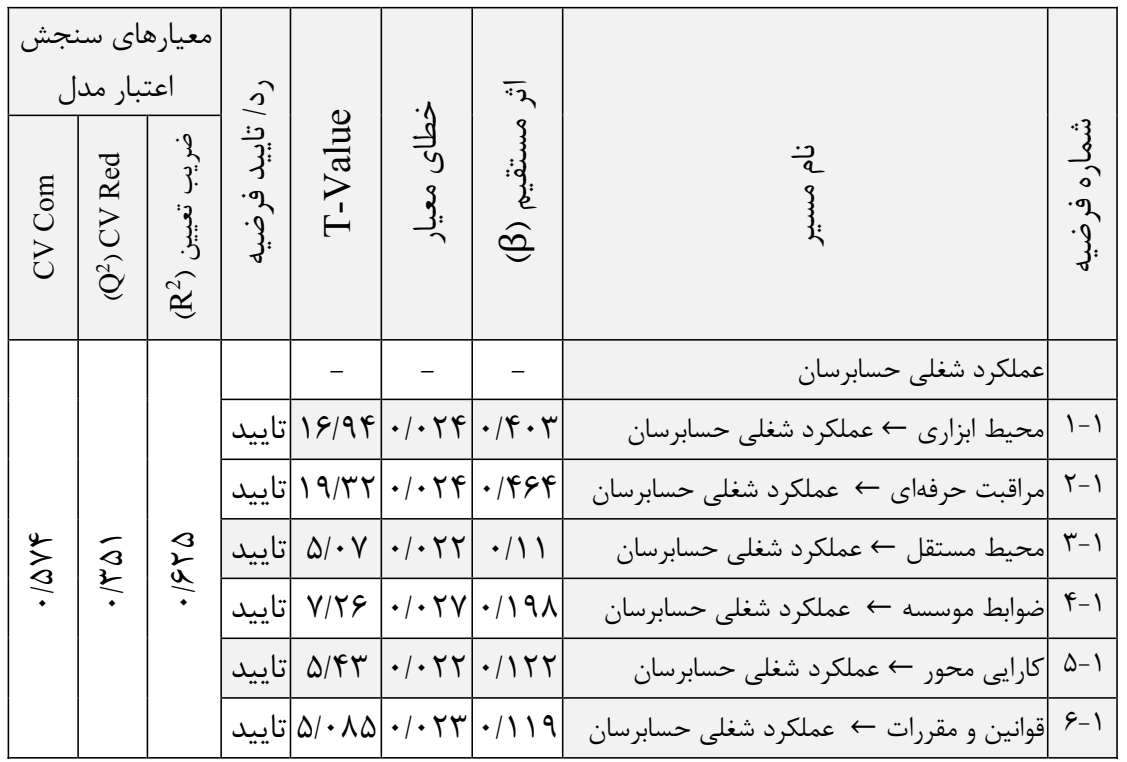

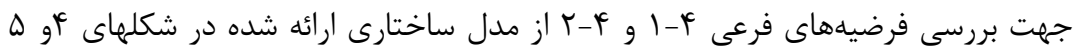

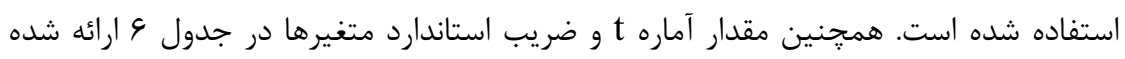


شايسته شجاعى و همكاران، تاثير معيارهاى رفتار اخلاقى بر عملكرد حسابرسان

شكل F - مدل معادلات ساختارى مربوط به فرضيههاى فرعى F - ا و F F (ضرايب

استاندارد شده)

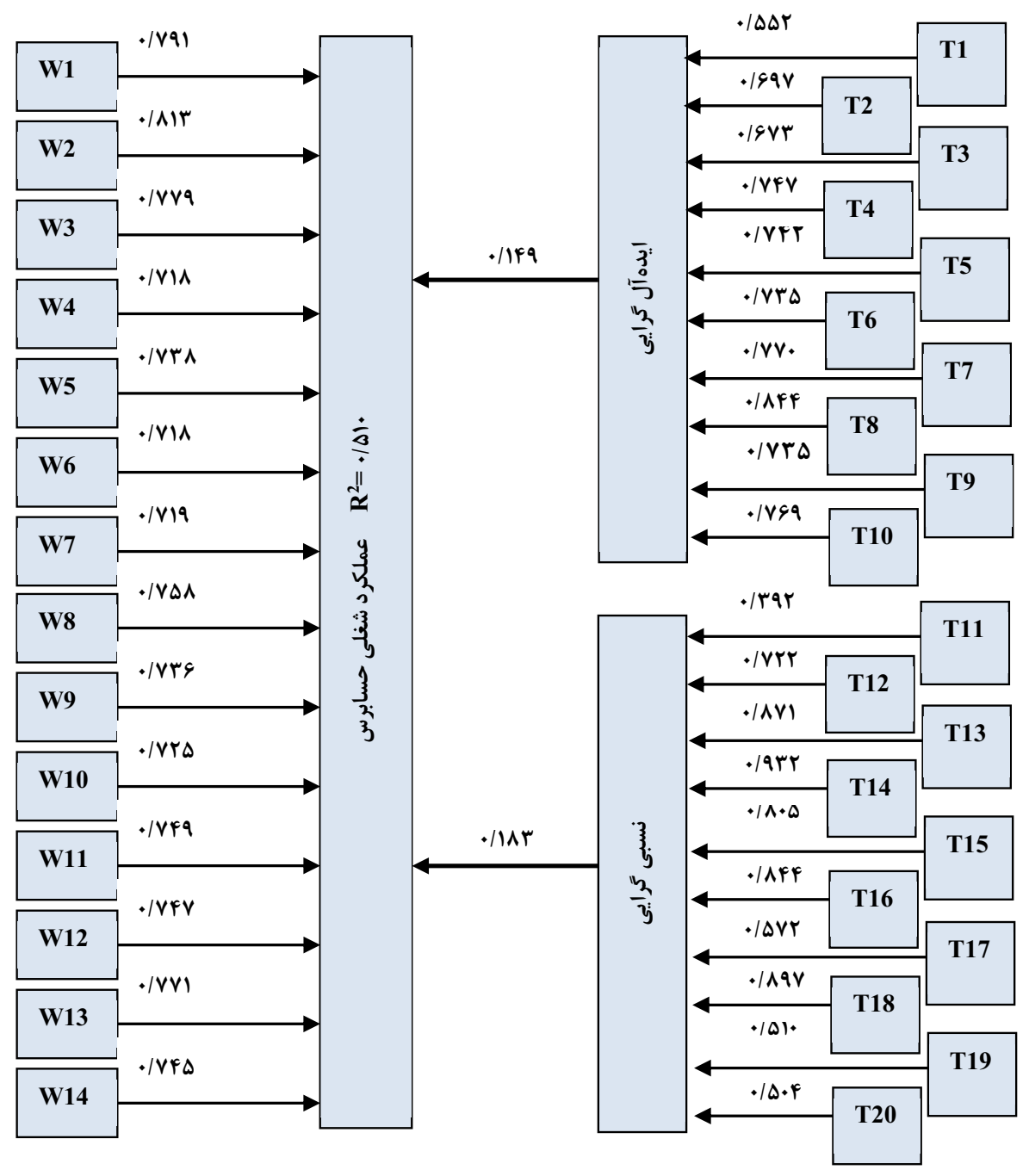


دو فصلنامه حسابدارى ارزشى و رفتارى، سال پِنجم، شماره دهم، پاييز و زمستان 99سا

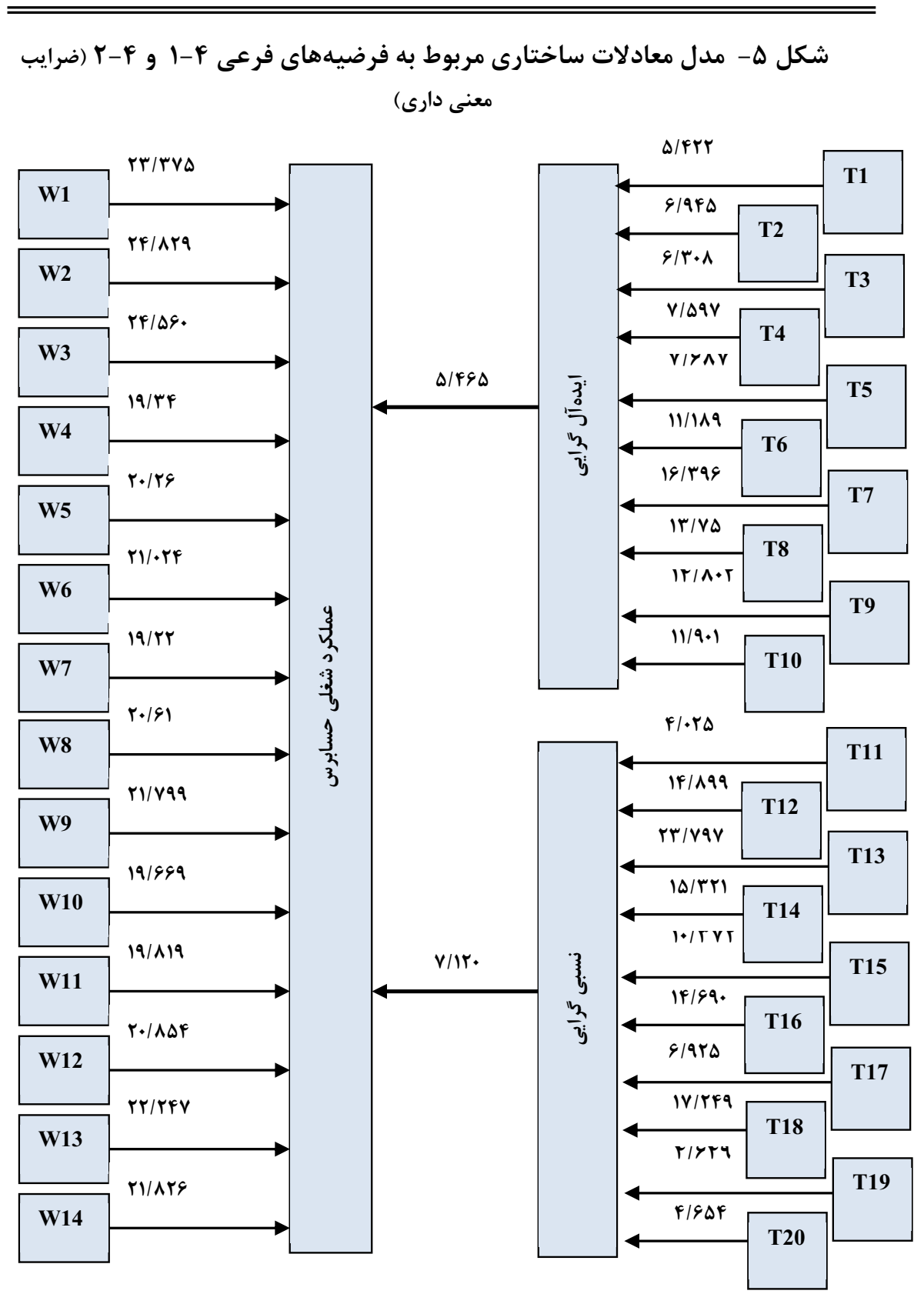




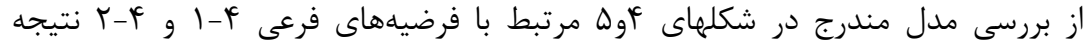

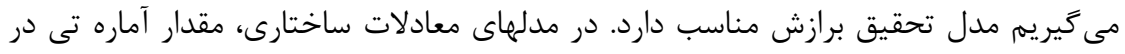

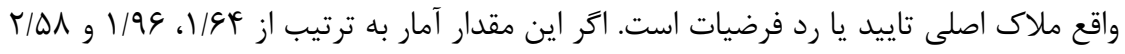

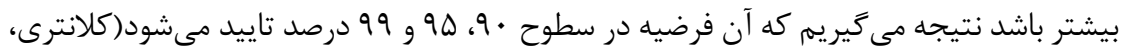

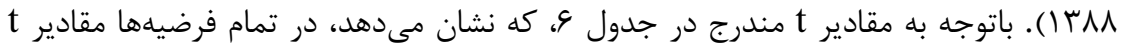

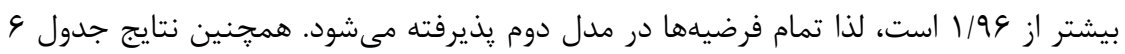

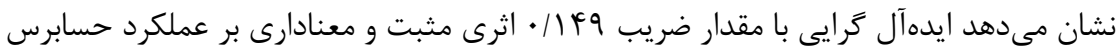

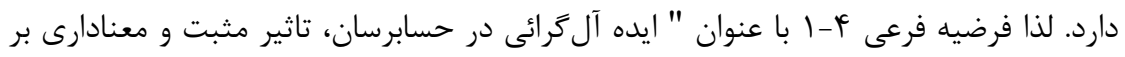

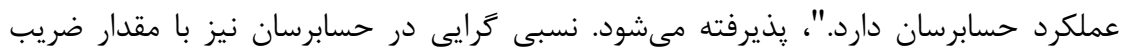

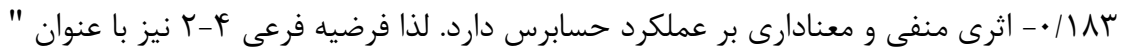

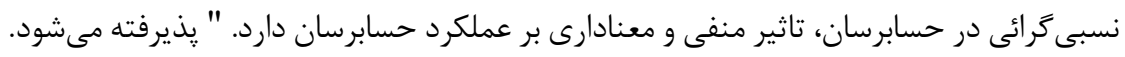

جدول 9- اثرات بر متغير عملكرد شغلى و مقادير كيفيت مدل در فرضيههاى فرعى F-1 و

\begin{tabular}{|c|c|c|c|c|c|c|c|c|}
\hline & & & & & & & & \\
\hline \multicolumn{3}{|c|}{ معيارهاى سنجش مدل } & \multirow[b]{2}{*}{$\begin{array}{l}\frac{1}{3} \\
\frac{3}{3} \\
3 \\
0 \\
3 \\
3\end{array}$} & \multirow[b]{2}{*}{$\begin{array}{l}\stackrel{0}{\frac{\pi}{\pi}} \\
\stackrel{1}{n}_{n}\end{array}$} & \multirow[b]{2}{*}{$\begin{array}{l}\text { y } \\
y \\
3 \\
3\end{array}$} & \multirow[b]{2}{*}{$\begin{array}{l}\overline{2} \\
3 \\
3 \\
\hat{2} \\
\hat{0}\end{array}$} & \multirow[b]{2}{*}{$\begin{array}{l}\dot{\vec{a}} \\
\dot{\xi} \\
\dot{\xi}\end{array}$} & \multirow[b]{2}{*}{$\begin{array}{l}3 \\
3 \\
0 \\
0 \\
.9 \\
3\end{array}$} \\
\hline $\begin{array}{l}\Xi \\
\text { 己 } \\
\text { 己 }\end{array}$ & 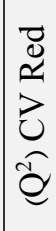 & 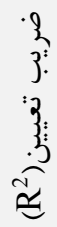 & & & & & & \\
\hline \multirow{3}{*}{$\begin{array}{l}\text { a } \\
\frac{a}{0}\end{array}$} & \multirow{3}{*}{$\stackrel{2}{i}$} & \multirow{3}{*}{$\frac{3}{3}$} & & - & - & - & |عملكرد شغلى حسابرسان & \\
\hline & & & تاييد & $\Delta / \& \& \Delta$ & $\cdot 1 \cdot t r$ & .1149 & |ايدهآل كرايى ـ عملكرد شغلى حسابرسان & $1-4$ \\
\hline & & & تاييد & $\mathrm{V} / \mathrm{TL}$ & $.1 \cdot 44$ & $-\cdot / \lambda \wedge r$ & نسبى كرايى ؟ عملكرد شغلى حسابرسان & $r-r^{2}$ \\
\hline
\end{tabular}

جهت بررسى فرضيههاى اصلى ا الى |f از مدل ساختارى ارائه شده در شكلهاى ؤ V استفاده شده است. همجنين مقدار آماره t و ضريب استاندارد متغيرها در جدول Vار ارائه شده است. 
دو فصلنامه حسابدارى ارزشى و رفتارى، سال ينجم، شماره دهم، پإييز و زمستان و9"1

ห97

شكل צ- مدل معادلات ساختارى مربوط به بر رسى فرضيههاى الى F (ضرايب استاندارد شده)

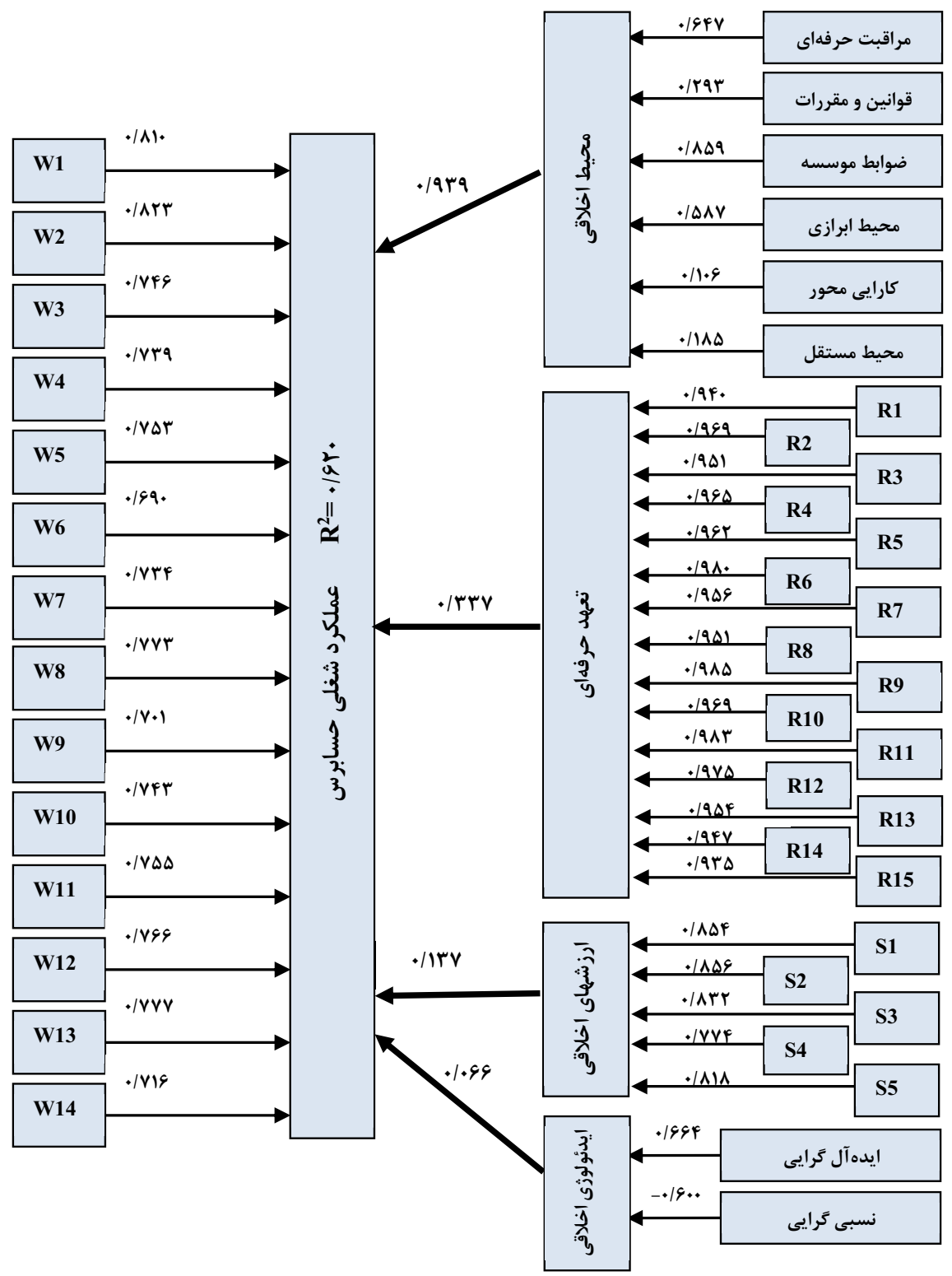


شايسته شجاعى و همكاران، تاثير معيارهاى رفتار اخلاقى بر عملكرد حسابرسان

شكل V- مدل معادلات ساختارى مربوط به بر رسى فرضيههاى اصلى ( الى f (ضرايب معنادارى)

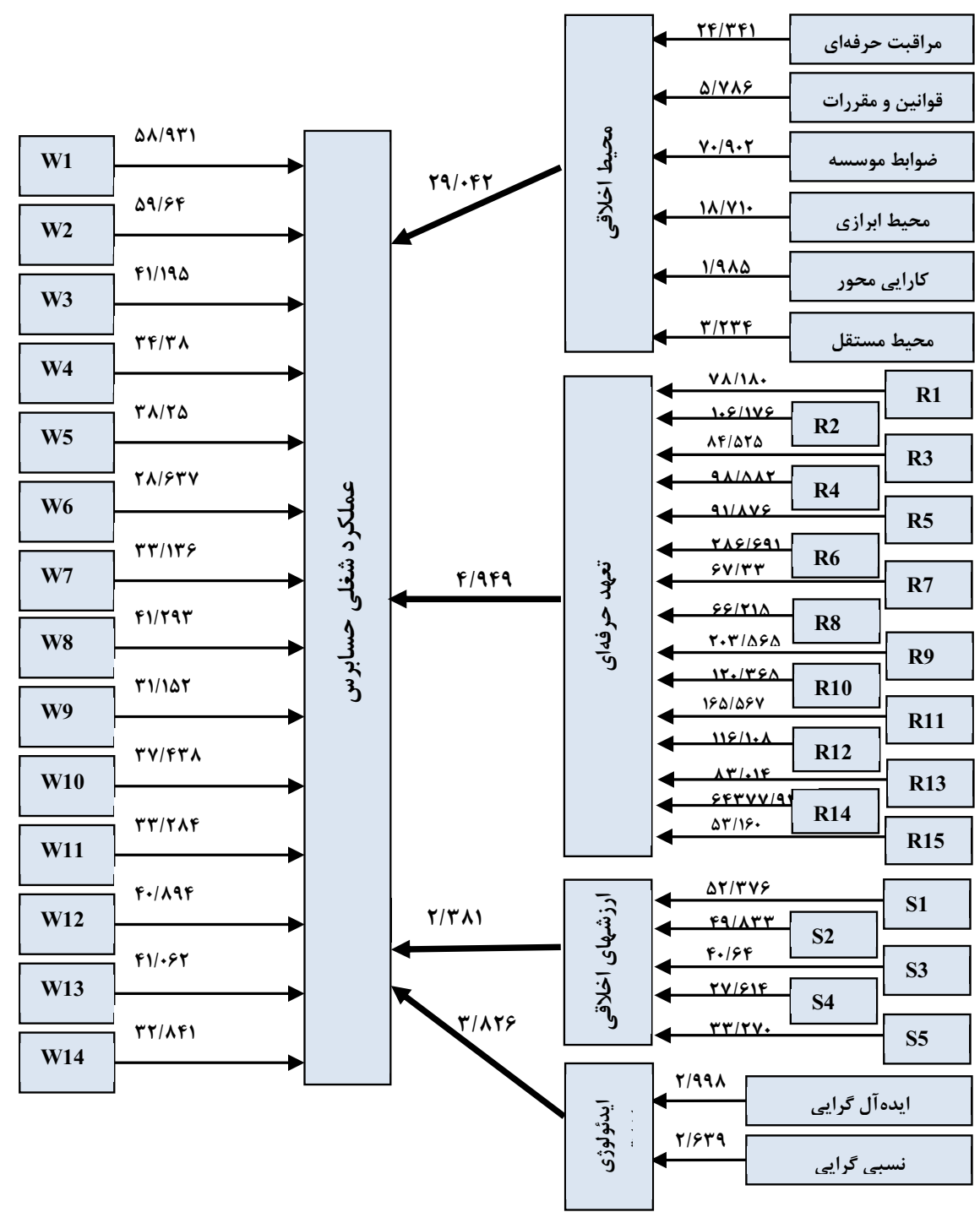




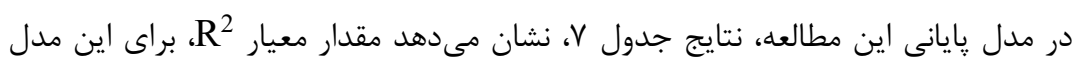

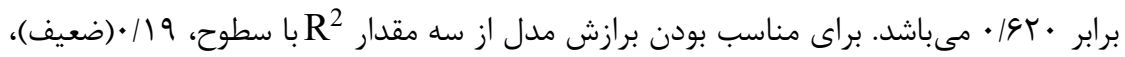

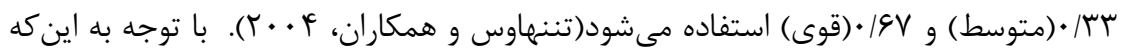

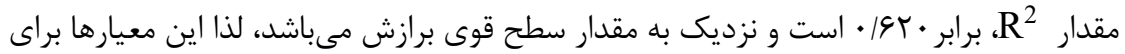

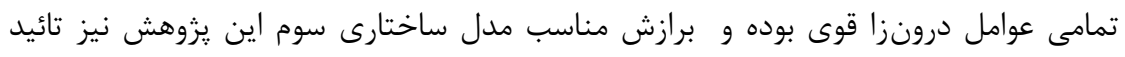

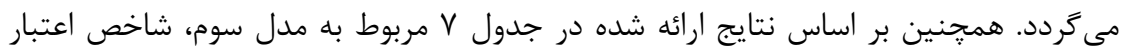

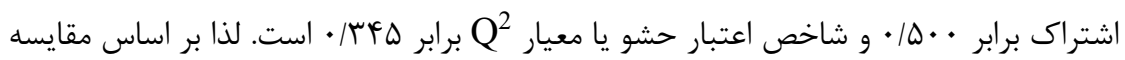

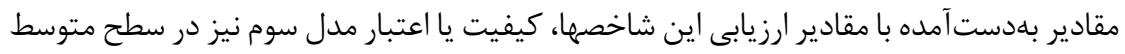

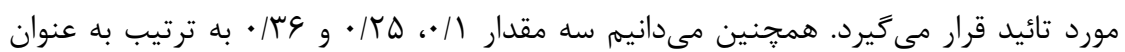

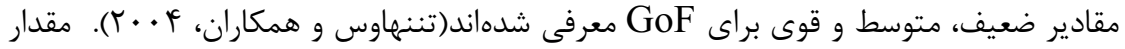

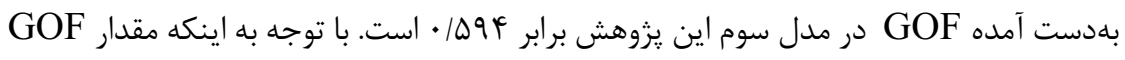

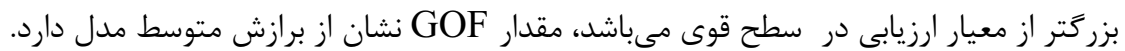

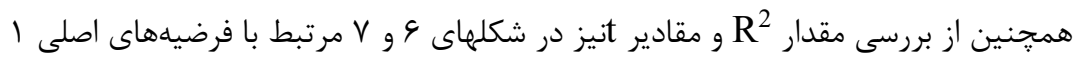

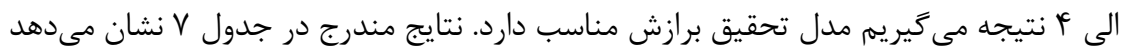

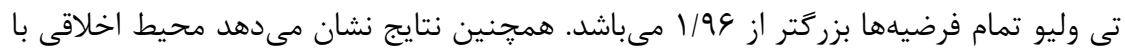

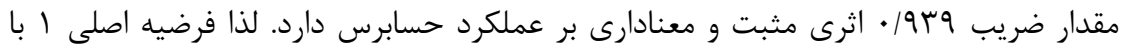

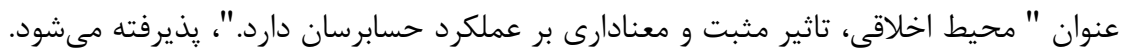

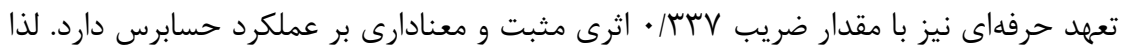

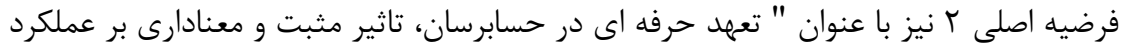

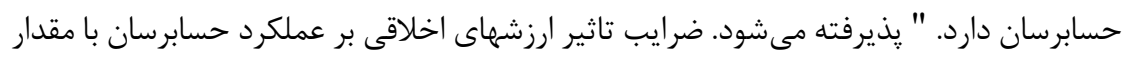

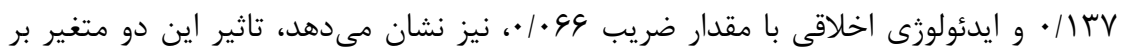

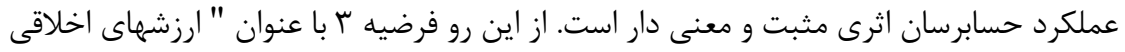

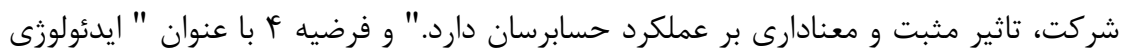

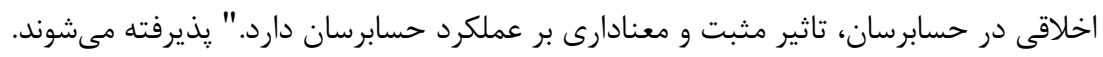


جدول V- اثرات بر متغير عملكردشغلى و مقاديركيفيت مدل درفرضيههاى اصلى Iالى F

\begin{tabular}{|c|c|c|c|c|c|c|c|c|}
\hline & ي سل سن & معيار & ก & & & $\sqrt{2}$ & & \\
\hline $\begin{array}{l}\Xi \\
\text { 己े } \\
z\end{array}$ & 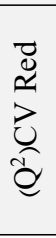 & $\begin{array}{l}2 \\
3 \\
3 \\
3 \\
3 \\
2 \\
\approx \approx \\
\approx\end{array}$ & $\begin{array}{l}13 \\
3 \vdots \\
3 \\
.2 \\
3 \\
3\end{array}$ & $\begin{array}{l}\stackrel{0}{\Xi} \\
\frac{\pi}{\pi} \\
\underbrace{\prime}\end{array}$ & $\begin{array}{l}\hat{y} \\
y \\
3\end{array}$ & $\begin{array}{l}\frac{\beta}{3} \\
\stackrel{3}{2} \\
\hat{n}\end{array}$ & $\begin{array}{l}\vec{a} \\
\vec{a} \\
\underline{3}\end{array}$ & $\begin{array}{l}3 \\
0 \\
0 \\
3 \\
3\end{array}$ \\
\hline & & & & - & - & - & | عملكرد شغلى حسابرسان & \\
\hline & & & 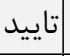 & $r q / \cdot r$ & . $1 \cdot r t$ &.$/ 949$ & محيط اخلاقى ؟ عملكرد شغلى حسابر سان & 1 \\
\hline$\dot{s}$ & 紫 & $\frac{2}{a}$ & |تاييد & $r / 94$ & $.1 \cdot 9 \wedge$ & • & تعهد حرفهاى ؟ عملكرد شغلى حسابرسان & $r$ \\
\hline & & & تاييد & $\Gamma / \Gamma \wedge$ & $\cdot / \cdot \Delta \Lambda$ &.$/ 1 r v$ & ارزش هاى اخلاقى ؟عملكرد شغلى حسابر سان & r \\
\hline & & & |تاييد & T/TT & $.1 . r$ & .1 .94 & ايدئولوزى اخلاقى ־كملكرد شغلى حسابرسان & r \\
\hline
\end{tabular}

مشكلات اخلاقى اخير حسابرسان در سراسر جهان سبب شده است، بسيارى از موسسات

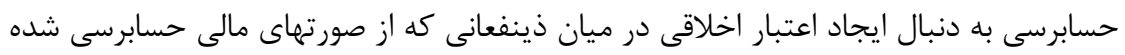
استفاده مى كنند، باشند.

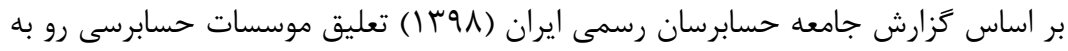

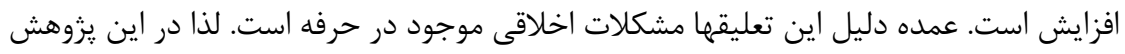
به بررسى تاثير معيارهاى رفتار اخلاقى شامل محيط اخلاقى(محيط ابزارى، محيط دلخواه، محيط

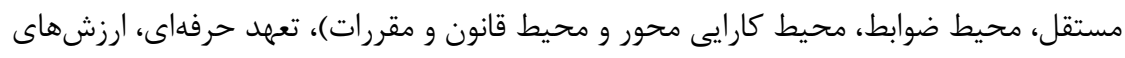

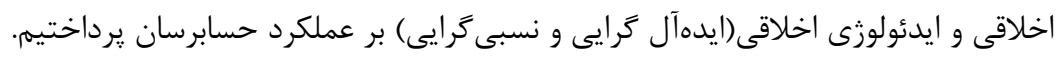

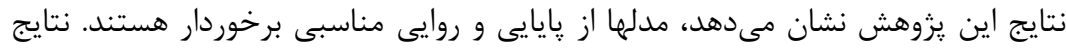

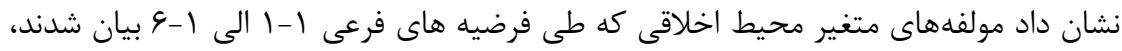

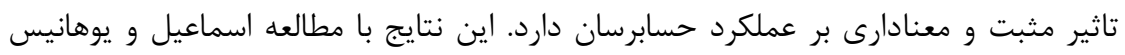

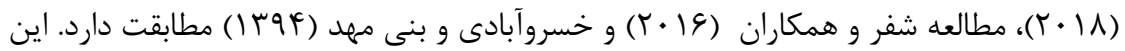

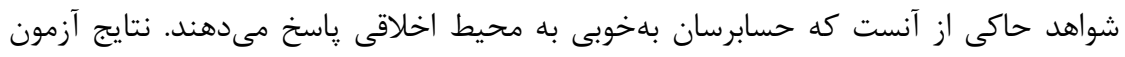

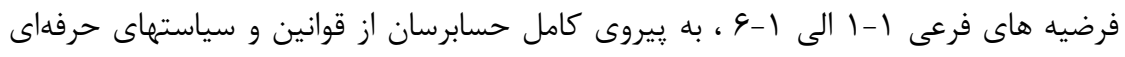

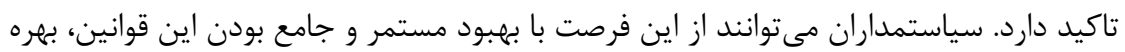

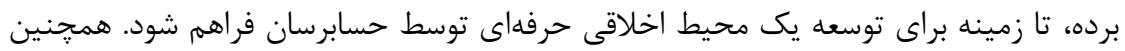


نتايج به توجه حسابرسان به قوانين اخلاقى حرفه و سازمان به جاى توجه به تمايلات شخصى

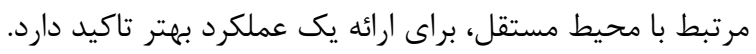

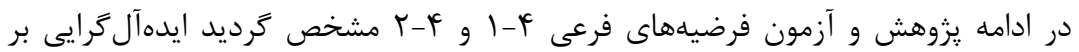

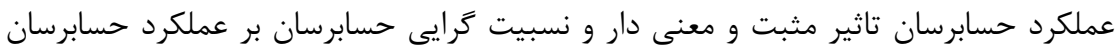

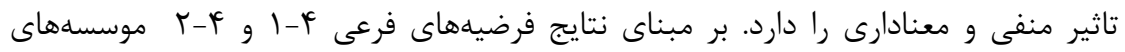

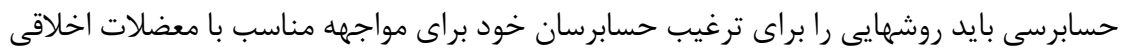

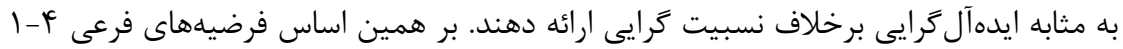

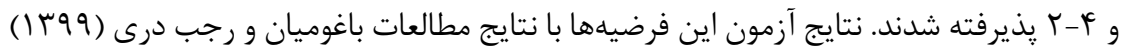

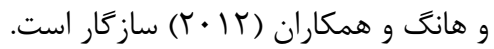
در ادامه به آزمون فرضيههاى اصلى الى الى أ يرداختيم. نتايج نشان داد تمامى متغيرهاى

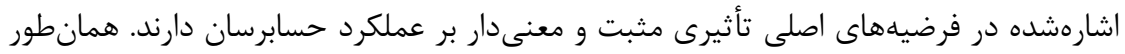

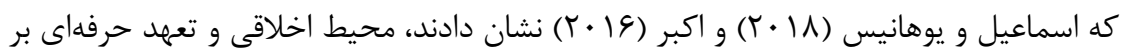

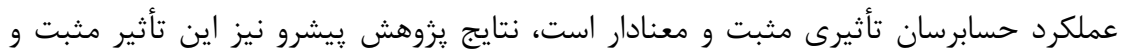

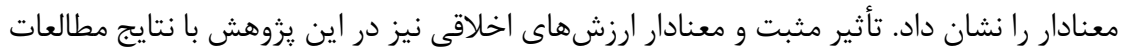

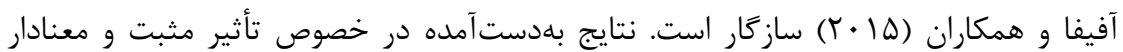

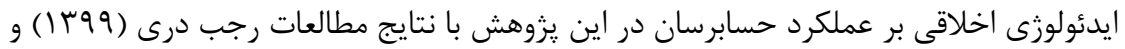

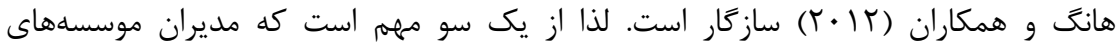

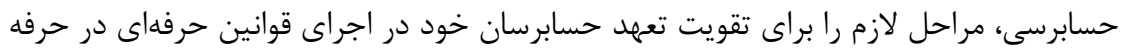

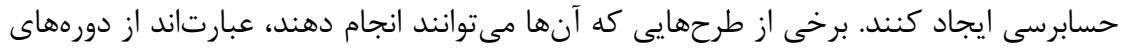

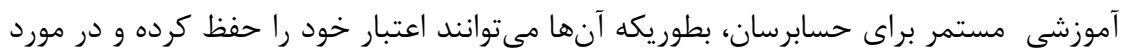
آخرين روندهاى حسابرسى اطلاع يابند.

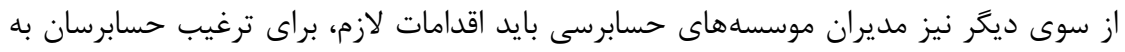

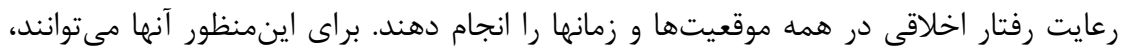

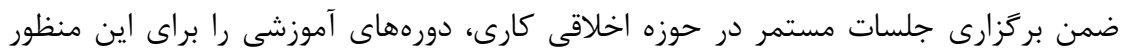

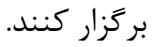

مطالعه حاضر به شناسايى عوامل مهمم تأثير كذار بر رفتار اخلاقى حسابرسان در ايران كمك

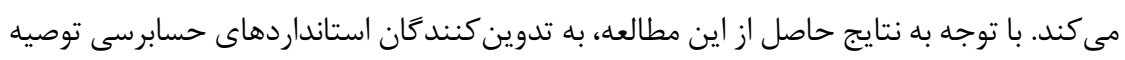

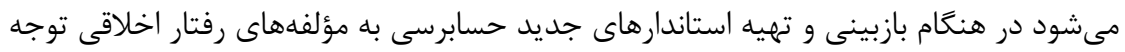

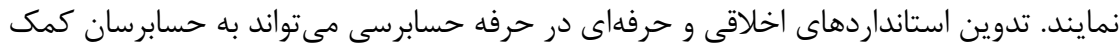

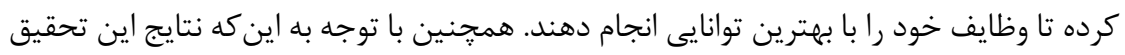


نشان داد محيط اخلاقى و حساسيتهاى اخلاقى مىتواند عملكرد حسابرسان را افزايش دهند،

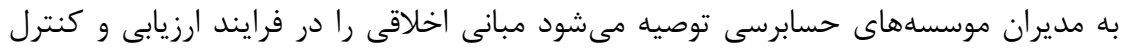

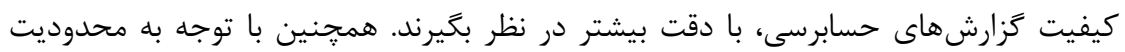

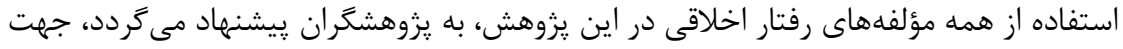

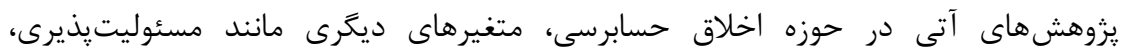

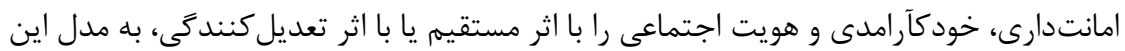
يزوهش اضافه و بر همان مبنا فرضيههاى موجود و جديد را مورد آزمون قرار دهند.

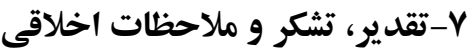

از كليه كسانى كه در راستاى انجام اين يزوهش واخلاف نسبت به تكميل و ارسال يرسشنامه اقدام

$$
\begin{aligned}
& \text { نمودند، كمال تشكر را داريم. } \\
& \text { 1- ييوستها }
\end{aligned}
$$

يرسشنامه محيط كارى اخلاقى بر اساس مدل ويكتور و كولن محيط اخلاقى(ويكتور و كالن، 1911 (1) )

\begin{tabular}{|c|c|c|c|c|c|c|}
\hline $\begin{array}{l}\frac{b}{3} \\
\bar{\lambda} \\
\frac{s}{20} \\
\frac{9}{2}\end{array}$ & $\frac{2}{12}$ & $\begin{array}{l}\text {-a } \\
y \\
3 \\
\frac{3}{2}\end{array}$ & . & 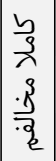 & 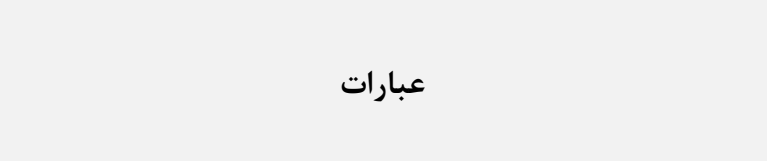 & 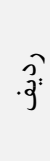 \\
\hline & & & & & 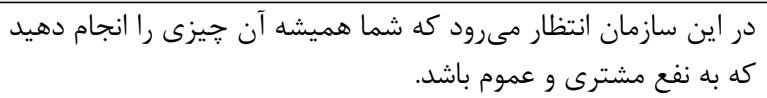 & 1 \\
\hline & & & & & 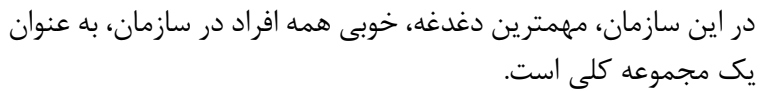 & r \\
\hline & & & & & 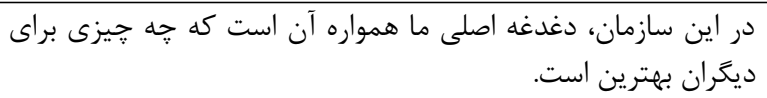 & r \\
\hline & & & & & در اين سازمان، افراد به دنبال رشد نيكىهاو خوبىهاى يكديكر هستند. & r \\
\hline & & & & & در اين سازمان، درنظركرفتن ملاحظات مهم سازمانى براى هركس، & $\Delta$ \\
\hline & & & & & 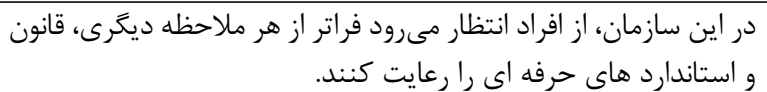 & 4 \\
\hline & & & & & در اين سازمان، قانون يا اصول اخلاقى حرفه اى ملاحظه اصلى است. & v \\
\hline & & & & & در راين سازمان از افراد انتظار مى رود تا قوانين و استانداردهاى حرفه & $\wedge$ \\
\hline
\end{tabular}

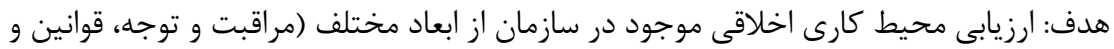


دو فصلنامه حسابدارى ارزشى و رفتارى، سال ينجم، شماره دهم، پإييز و زمستان وجسا

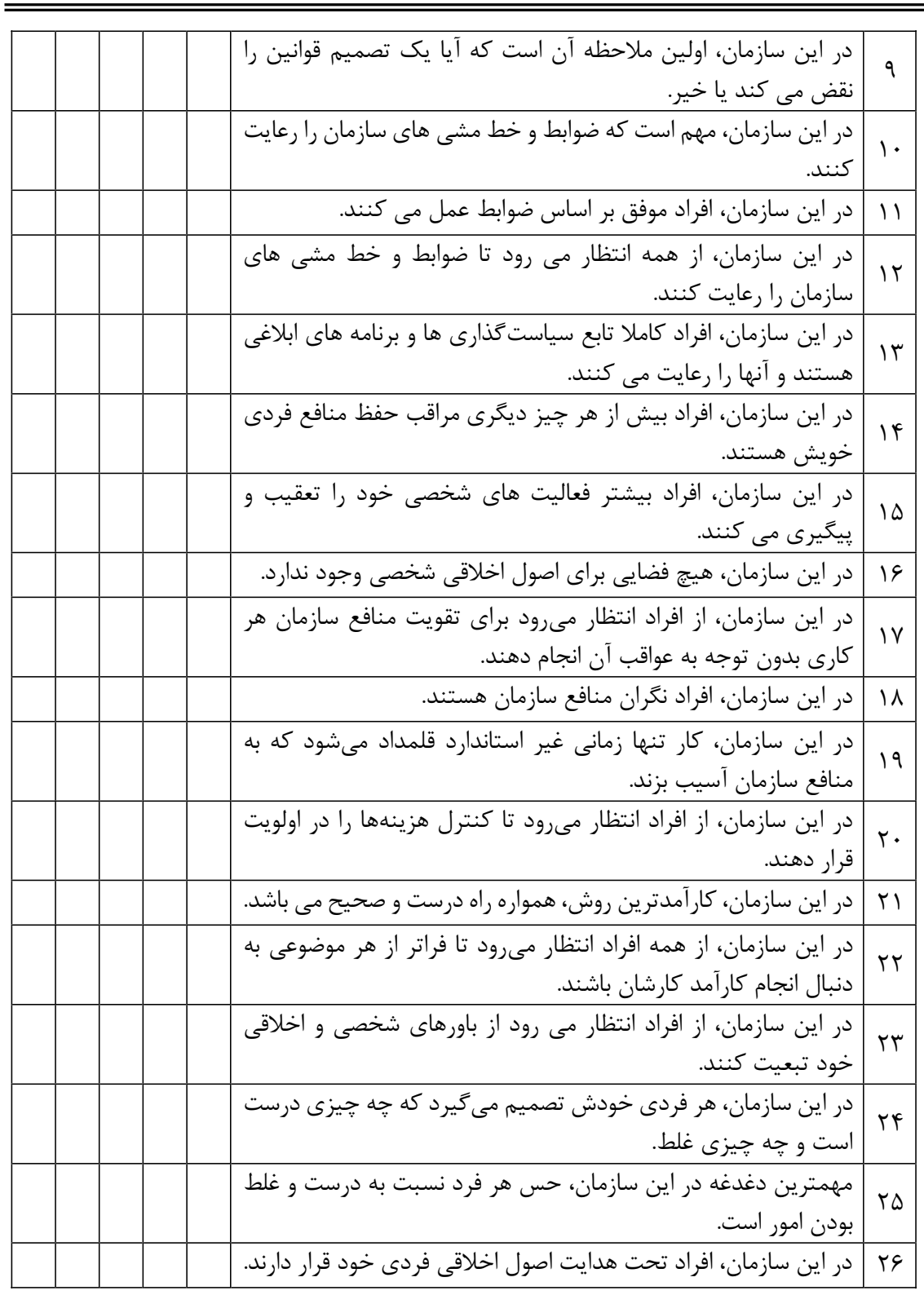


شايسته شجاعى و همكاران، تاثير معيارهاى رفتار اخلاقى بر عملكرد حسابرسان

يرسشنامه تعهد حرفه اى تعهد حرفهاى(كلاكمن و هنينغ، •+"广)

هدف: ارزيابى يرسشنامه تعهد حرفه اي حسابرسان

\begin{tabular}{|c|c|c|c|c|c|c|}
\hline $\begin{array}{l}\frac{b}{3} \\
\lambda \\
\frac{g}{2} \\
\frac{2}{2}\end{array}$ & $\frac{2}{2}$ & $\begin{array}{l}: a{ }^{2} \\
\text { y } \\
\frac{3}{2}\end{array}$ & . & 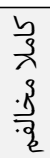 & عبارات &.$\hat{a}$ \\
\hline & & & & & حرفهام از خود نشان دارم تلاشى بيش از حد مورد انتظار براى موفقيت در & 1 \\
\hline & & & & & ياد مى از اينم. حرفه در ميان دوستان خود به عنوان حرفهاى بزرگ & r \\
\hline & & & & & من حس وفادارى كمى نسبت به اين حرفه دارم. & r \\
\hline & & & & & 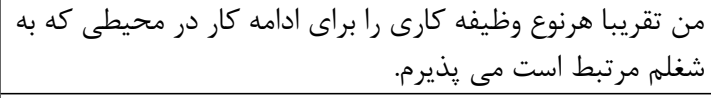 & r \\
\hline & & & & & من دريافتم كه ارزشهاى من و ارزشهاى شغلم مشابه هستند. & $\Delta$ \\
\hline & & & & & مرفه بسيار افتخار مى كنم كه به ديخران بكويم من بخشى از اين & द \\
\hline & & & & & 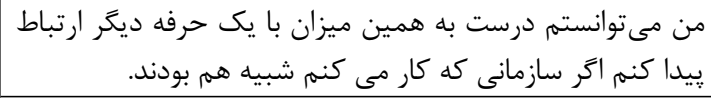 & v \\
\hline & & & & & 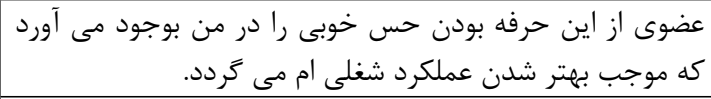 & $\wedge$ \\
\hline & & & & & 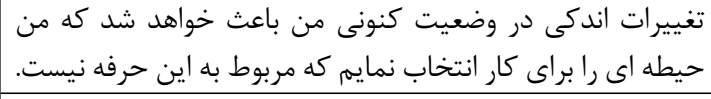 & 9 \\
\hline & & & & & ديخر مشى نهايت خوشحالم كه در زمان انتخاب شغل اين حرفه را بر & $1 \cdot$ \\
\hline & & & & & آوردن بدارد. طامحدودى به اين حرفه بيردازم جيز زيادى براى بدست & 11 \\
\hline & & & & & غالبا هم عقيده بودن با سياستهاى حرفه را در مسايل مهم مربوط & it \\
\hline & & & & & واقعا آينده اين حرفه برايم اهميت دارد. & ir \\
\hline & & & & & براى من اين حرفه بهترين حرفه در ميان تمامى حرفههاست. & if \\
\hline & & & & & تصميم ورود به اين حرفه يك اشتباه قطعى از جانب من بود. & 10 \\
\hline
\end{tabular}


دو فصلنامه حسابدارى ارزشى و رفتارى، سال ينجم، شماره دهم، پإييز و زمستان وجسا

يرسشنامه اخلاق سازمانى هانت و همكاران (CEP)(هانت و ويتل، 191).

\begin{tabular}{|c|c|c|c|c|c|c|c|c|}
\hline 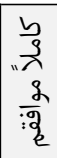 & $\begin{array}{l}\frac{1}{3} \\
\frac{2}{2} \\
\frac{1}{2}\end{array}$ & $\begin{array}{l}y \\
\frac{\xi}{2}\end{array}$ & $\begin{array}{l}j \\
: \frac{a}{a} \\
a\end{array}$ & $\begin{array}{l}3 \\
3 \\
3 \\
3 \\
3\end{array}$ & 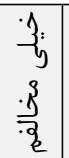 & 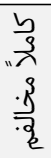 & عبارات & . \\
\hline & & & & & & & 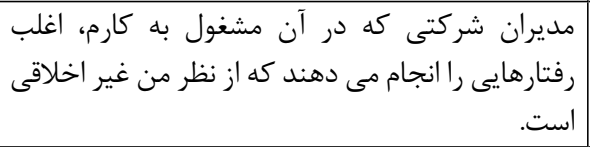 & 1 \\
\hline & & & & & & & 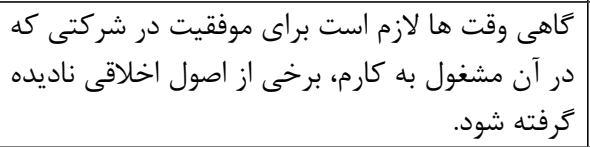 & $r$ \\
\hline & & & & & & & 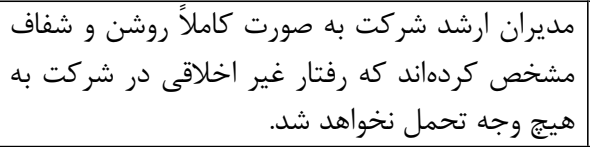 & $r$ \\
\hline & & & & & & & 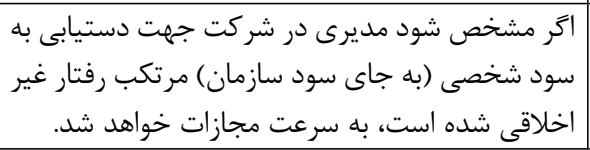 & f \\
\hline & & & & & & & 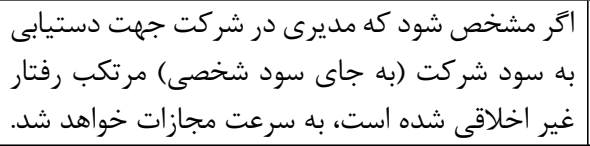 & $\Delta$ \\
\hline
\end{tabular}

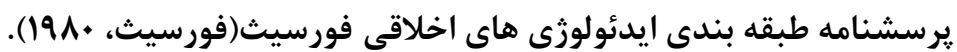

\begin{tabular}{|c|c|c|c|c|c|c|c|c|c|c|}
\hline \multicolumn{11}{|c|}{ هدف: بررسى ايده آل زرايى و نسبيت قوانين اخلاقى } \\
\hline $\begin{array}{l}\frac{b}{3} \\
\frac{3}{2} \\
\frac{2}{2} \\
2\end{array}$ & $\frac{2}{9}$ & $\begin{array}{l}\vdots 2 \\
3 \vdots \\
\frac{3}{3} \\
\frac{3}{2}\end{array}$ & $\begin{array}{l}\overline{3} \\
y \\
\frac{2}{2}\end{array}$ & $: 3$ & $\begin{array}{l}\overline{3} \\
\eta_{3} \\
.5 \\
. \overline{3}\end{array}$ & 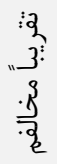 & .9 & 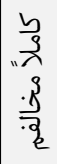 & 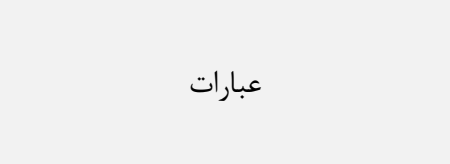 &.$\hat{\jmath}$ \\
\hline & & & & & & & & & هايش به شخص بايد مطمئن باشد كه فعاليت & 1 \\
\hline & & & & & & & & & نبايد با در مخاطره قرار دادن ديكران، & r \\
\hline & & & & & & & & & 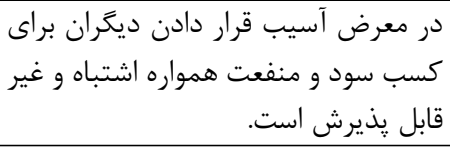 & r \\
\hline
\end{tabular}




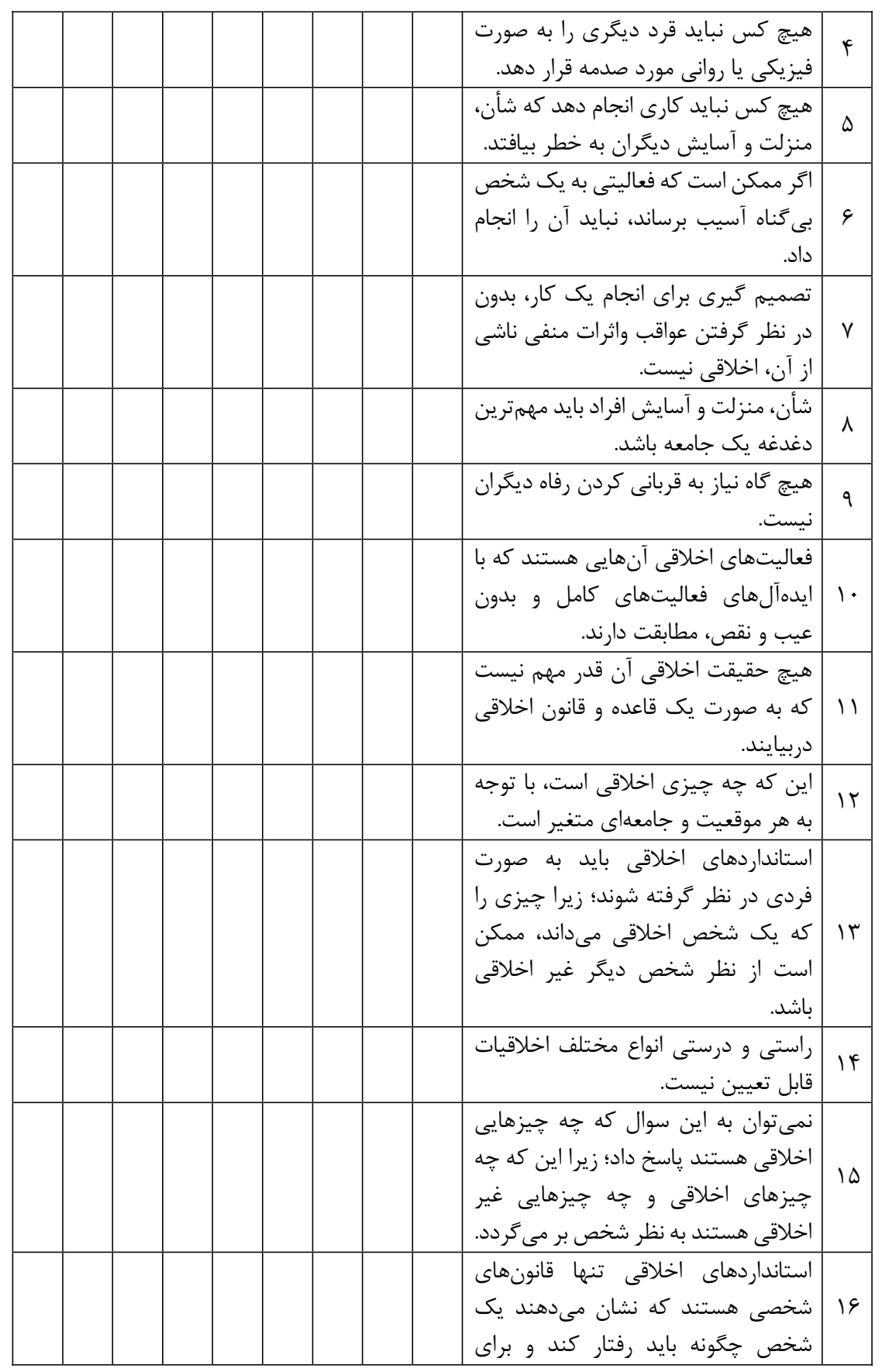


دو فصلنامه حسابدارى ارزشى و رفتارى، سال ينجم، شماره دهم، پإييز و زمستان وجسا

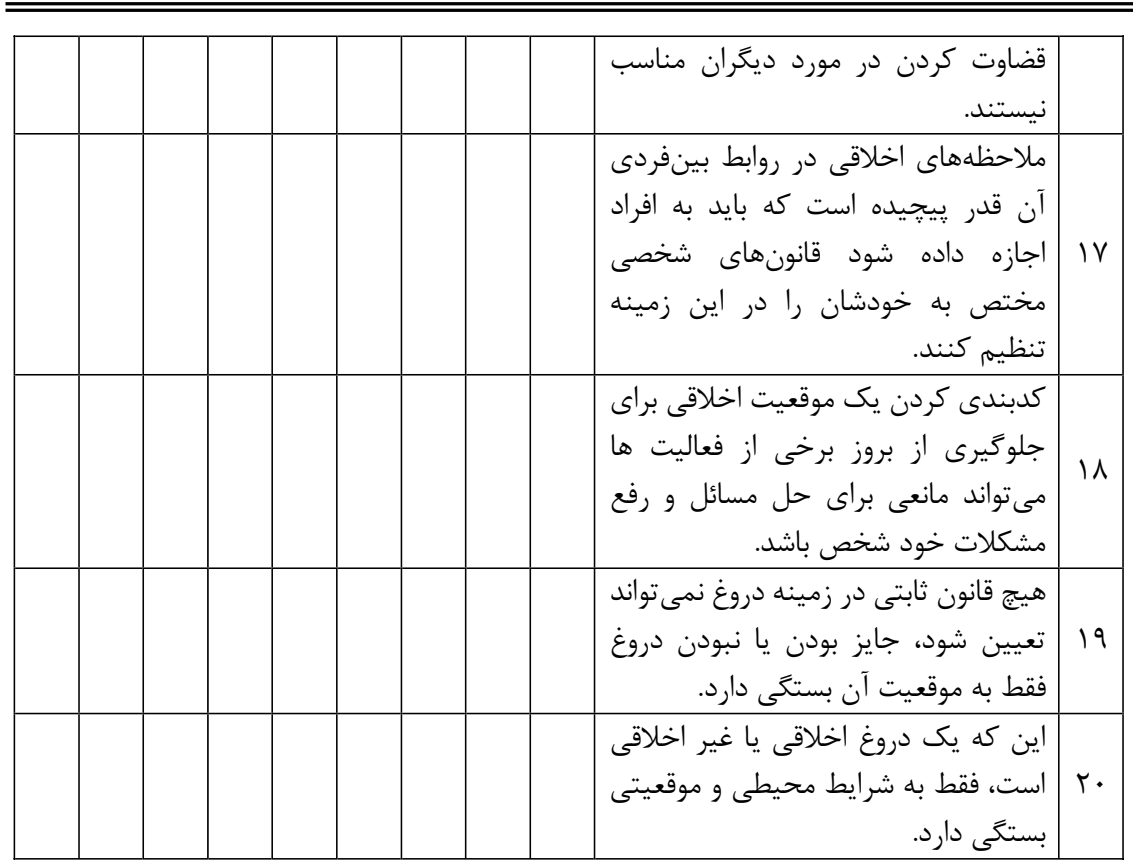

يرسشنامه ارزيابى عملكرد حسابرسان (يورستا و توفيكور، \&(†).

\begin{tabular}{|c|c|c|c|c|c|c|}
\hline $\begin{array}{l}3 \\
\frac{3}{3} \\
\frac{2}{2}\end{array}$ & $\begin{array}{l}y \\
y \\
\frac{2}{2}\end{array}$ & $\begin{array}{l}\text {-a } \\
y \\
3 \\
\frac{3}{2}\end{array}$ & $\begin{array}{l}3 \\
3 \\
3 \\
3 \\
3\end{array}$ & 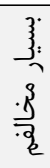 & 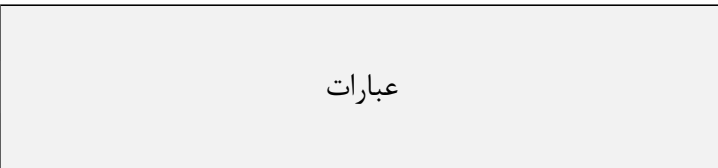 & $\hat{\jmath}$ \\
\hline & & & & & من از نظر كمى، از نتيجه كارى كه انجام مى دهم راضى هسته. & 1 \\
\hline & & & & & من از نظر كيفى، از نتيجه كارى كه انجام مى دهم راضى هستم. & r \\
\hline & & & & & من از حجم كار روزانهاى كه انجام مى دهم راضى هسته. & r \\
\hline & & & & & من از ميزان مهارتهاى ارتباط كلامىام راضى هسته. & r \\
\hline & & & & & من از مهارتهاى ارتباط نوشتارىام راضى هستم. & $\Delta$ \\
\hline & & & & & راضى هستم. رايى خود براى پذيرش مسئوليتها و انجام كار مشخص & 4 \\
\hline & & & & & 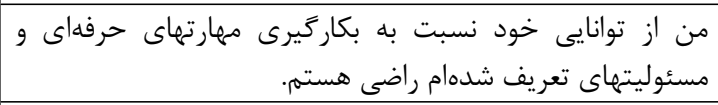 & v \\
\hline & & & & & هنت از توانيى خود براى بِيروى كردن از رويهها و رهنمودها راضى & $\wedge$ \\
\hline & & & & & هن از توانايى خود براى برنامهريزى و سازماندهى كارهايم راضى & 9 \\
\hline
\end{tabular}




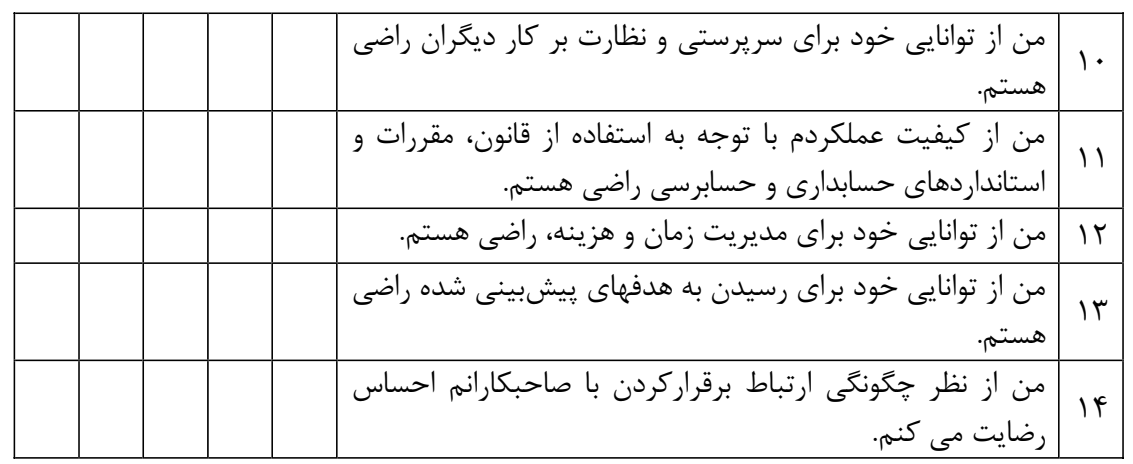

\section{فهرست منابع}

باغوميان، رافيك و رجبدرُى، حسين. (ج9 (1))، رابطه بين ايدئولوزى اخلاقى و استرس حسابداران

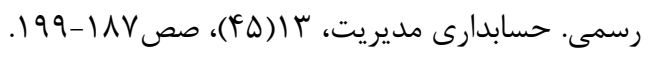

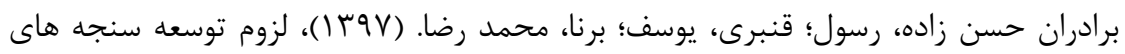

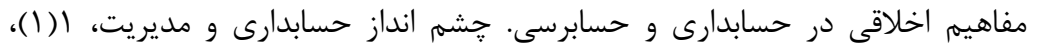

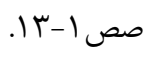

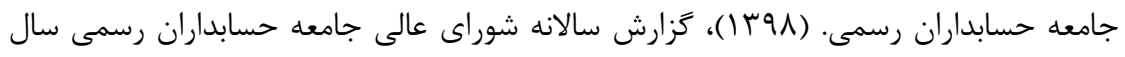

$$
.1491
$$

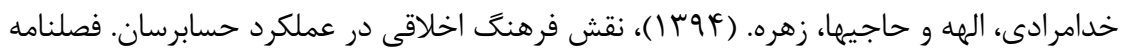

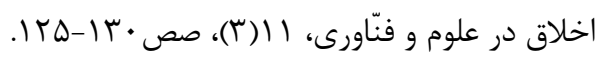

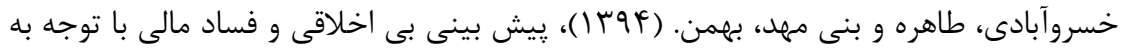

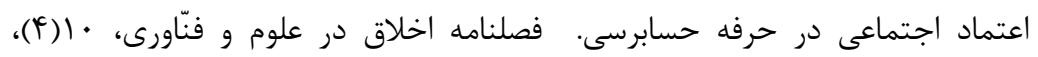

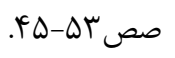

رمضان احمدى، محمد؛ آهنكَرى؛ عبدالمجيد، صالحى نيا؛ محسن. (

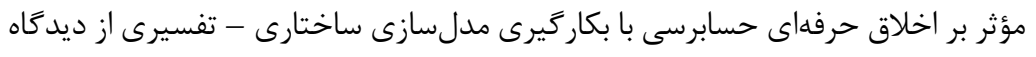

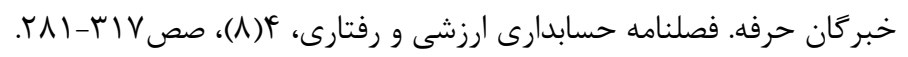

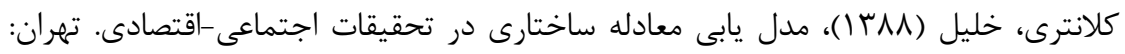

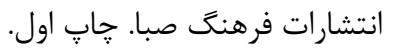

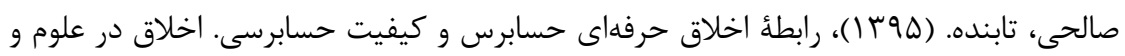

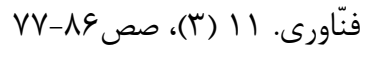




$$
\begin{aligned}
& \text { طباطبائى، سيدسجاد و لسانى، مهدى. (هوب ()، اعتباريابى آمادگى فرصتيابى حرفه اى مبتنى }
\end{aligned}
$$

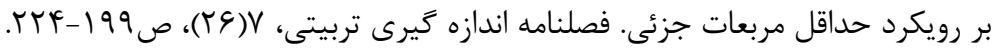

$$
\begin{aligned}
& \text { علوى، سيد محمد. (1) (1))، عوامل و موانع كيفيت حسابرسى در ايران. فصلنامه حسابدار رسمى. }
\end{aligned}
$$

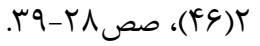

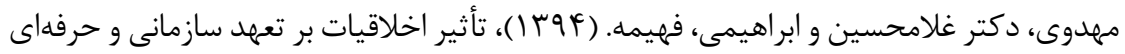

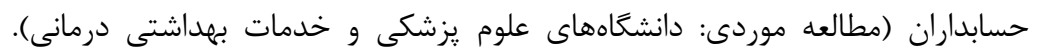

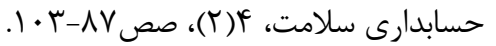

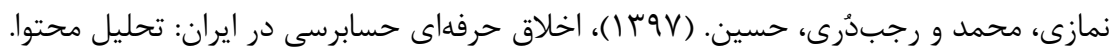

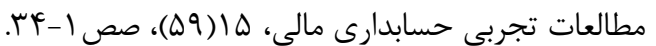

Afifah، U.، R. N. Sari.، R، Anugerah. And Z. M. Sanusi. 2015. The effect of role conflict، self-efficacy، professional ethical sensitivity on auditor performance with emotional quotient as moderating variable. Procedia Economics and Finance 31: 206-212.

Akbar، M. 2016. Pengaruh Komitmen Profesional، Efikasi Diri، dan Tekanan Ketaatan terhadap Pengambilan Keputusan Etis Auditor dengan Pertimbangan Etis sebagai Variabel Moderating (Studi Empiris pada Kantor Akuntan Publik di Kota Makassar). Universitas Islam Negeri Alauddin Makassar.

Asry، S. And H، Ginting. 2020. Effect of Professional Ethics and Emotional Intelligence on Auditor Performance. Journal of Research in Business، Economics، and Education 2(3): 576-589.

Bakri، B. 2014. Analisis komitmen profesional dan sosialisasi antisipatif serta hubungannya dengan Whistleblowing. Al-Mizan، 10(1)، 152-167.

Bonner, S. E. (1994). A model of the effects of audit task complexity. Accounting, organizations and society, 19(3), 213-234.

Clikeman، P. M.، And Henning، S. L. 2000. The socialization of undergraduate accounting students. Issues in Accounting Education 15(1): 1-17.

Drozd, I., M, Pysmenna., \& V, Volkov. (2020). Management Of Ethical Behavior Of Auditors. Baltic Journal of Economic Studies 6(4): 66-71.

Deshpande، S. P.، J، Joseph. And X، Shu. 2011. Ethical climate and managerial success in China. Journal of Business Ethics 99(4): 527-534.

Dewi، P. P.، And K. T، Dwiyanti. 2018. Professional commitment، self-efficacy and ethical decision auditor. International research journal of management، IT and social sciences 5(6): 93-104.

Drozd، I.، M، Pysmenna. A And V، Volkov. 2020. MANAGEMENT OF ETHICAL BEHAVIOR OF AUDITORS. Baltic Journal of Economic Studies 6(4): 6671.

Fishbein، M. And I، Ajzen. 2010. Prediction and change of behavior: The reasoned action approach. In: New York: Psychology Press.

Forsyth، D. R. 1980. A taxonomy of ethical ideologies. Journal of Personality and Social psychology 39(1): 175. 
Gibson، J.، J، Ivancevich.، And R، Konopaske. 2011. Organizations: Behavior، structure، processes: McGraw-Hill Higher Education.

Huang، C.-C.، C.-S، You.' And M.-T، Tsai. 2012. A multidimensional analysis of ethical climate، job satisfaction، organizational commitment، and organizational citizenship behaviors. Nursing ethics 19(4): 513-529.

Hunt، S. D. ' And S، Vitell. 1986. A general theory of marketing ethics. Journal of macromarketing 6(1): 5-16.

Ismail, S. 2015. Influence of emotional intelligence, ethical climates, and corporate ethical values on ethical judgment of Malaysian auditors. Asian Journal of Business Ethics 4(2): 147-162.

Ismail، S.، And N، Yuhanis. 2018. Determinants of ethical work behaviour of Malaysian public sector auditors. Asia-Pacific Journal of Business Administration 10(1):21-34

Iyer، V. M. A، Jones III.، And Raghunandan، K. 2018. Factors related to internal auditors' organizational-professional conflict. Accounting Horizons 32(4): 133-146.

Janitra، W. A.، H، Hardi. And M، Wiguna. 2017. Pengaruh Orientasi Etika، Komitmen Profesional، Komitmen Organisasi، dan Sensitivitas Etis terhadap Internal Whistleblowing (Studi Empiris pada Skpd Kota Pekanbaru). Riau University.

Kish-Gephart، J. J.، D. A، Harrison.، And L. K، Treviño. 2010. Bad apples‘ bad cases، and bad barrels: meta-analytic evidence about sources of unethical decisions at work. Journal of applied Psychology 95(1): 1-31.

Mansor، T. M. T.، A. M، Ariff.، And H. A، Hashim. 2020. Whistleblowing by auditors: the role of professional commitment and independence commitment. Managerial Auditing Journal 35(8): 1-23.

Morales-Sánchez، R.، M، Orta-Pérez. And Rodríguez-Serrano، M. Á. 2019. The Benefits of Auditors' Sustained Ethical Behavior: Increased Trust and Reduced Costs. Journal of Business Ethics 166(8): 1-19.

Nugraha، T.، N، Azlina.، And J، Julita. 2017. Pengaruh Komitmen Profesional، Lingkungan Etika، Sifat Machiavellian Dan Personal Cost Terhadap Intensi Whistleblowing Dengan Retaliasi Sebagai Variabel Moderating (Studi Empiris Pada Perusahaan Perbankan Yang Berada Di Kota Pekanbaru). Riau University 4(1): 2030-2044.

Poór‘ J، R، Alas.، S، Vanhala.، P، Kollár. A، Slavic.، N، Berber.‘ . . Ferencikova، S. 2015. Idealism and relativism in ethics: The results of empirical research in seven CEE countries \& one North European country. Journal of East European Management Studies 29(1): 484-505.

Shafer، W. E.، R. S، Simmons.، And R. W، Yip. 2016. Social responsibility، professional commitment and tax fraud. Accounting، Auditing \& Accountability Journal 29(1): 111-134.

Shafer، W. E.، And Z، Wang. 2010. Effects of ethical context on conflict and commitment among Chinese accountants. Managerial Auditing Journal 25(4): $377-400$. 
دو فصلنامه حسابدارى ارزشى و رفتارى، سال ينجم، شماره دهم، پإييز و زمستان و9"1

Tenbrunsel، A. E. A And K، Smith-Crowe. 2008. 13 ethical decision making: where We've been and where We're going. Academy of management Annals 2(1): 545-607.

Tenenhaus، M. S، Amato. A And V، Esposito Vinzi. 2004. A global goodness-of-fit index for PLS structural equation modelling. Paper presented at the Proceedings of the XLII SIS scientific meeting 2(1): 739-742.

Yuresta, D., \& S. E, Taufikur Rahman. 2011. Analisis Pengaruh Motivasi, Stres, Reward dan Rekan Kerja terhadap Kinerja auditor di Kantor Akuntan Publik (Doctoral dissertation, [Yogyakarta]: Universitas Gadjah Mada).

Victor، B. And J. B، Cullen. 1988. The organizational bases of ethical work climates. Administrative science quarterly 33(1): 101-125 